\title{
Technical signs in early medieval manuscripts copied in Irish minuscule
}

\author{
Evina Steinová \\ Huygens ING, KNAW
}

In the recent decades, projects such as the one that led to the production of this volume have made us aware of the value of marginal annotations for the understanding of early medieval intellectual culture. ${ }^{1}$ Glosses, commentaries, and other marginalia receive ever increasing attention, which is best manifested in the growing number of their editions and of studies dedicated to the phenomenon of annotating the manuscript book. ${ }^{2}$ Nevertheless, some types of marginalia that can be encountered in early medieval Latin manuscripts still escape our full grasp, being difficult to describe, examine systematically, and interpret. A particularly elusive category in this regard are technical signs, marginalia that have the form of symbols rather than words or images. ${ }^{3}$ Nota monograms that will be familiar to all adept at working with medieval manuscripts are one example of such technical signs, used in the Latin-writing world at least since the fifth century to mark passages of interest, literally beseeching one to 'pay attention' at a certain spot. ${ }^{4}$ They also illustrate some of the problems that technical signs pose to modern scholars. Even though they allow us to identify verses or lines of text that attracted the attention of medieval readers, it is notoriously difficult to interpret their precise function in specific manuscripts. ${ }^{5}$ Was the interesting aspect that warranted the use of nota signs the sophisticated theological or philosophical argument running through the text? Or was it rather something more

\footnotetext{
1 This article came into being as a part of the NWO VIDI project Marginal Scholarship: the Practice of Learning in the Early Middle Ages supervised by prof. Mariken Teeuwen. I would like to thank Jesse Keskiaho, Warren Pezé, Giorgia Vocino and Pádraic Moran for helpful comments on an earlier draft of this article.

${ }^{2}$ For recent works devoted to marginalia, see for example J.E.G. ZETZEL, Marginal Scholarship and Textual Deviance. The Commentum Cornuti and the Early Scholia on Persius (London, 2005); 'Scientia in margine': études sur les 'Marginalia' dans les manuscrits scientifiques du Moyen Age à la Renaissance, ed. D. JACQUART and C. BURNETT (Genève, 2005); H. MAYR-HARTING, Church and Cosmos in Early Ottonian Germany: The View from Cologne (Oxford, 2007); R. BERGMANN and S. STRICKER, Die Althochdeutsche und Altsächsische Glossographie, 2 vols. (Berlin, 2009); Carolingian Scholarship and Martianus Capella: Ninth-Century Commentary Traditions on 'De Nuptiis' in Context, ed. M. TEEuWEN and S. O'Sullivan (Turnhout, 2011); and M. SCHIEGG, Frühmittelalterliche Glossen: Ein Beitrag zur Funktionalität und Kontextualität mittelalterlicher Schriftlichkeit (Heidelberg: Winter, 2015). See also digital editions such as the one of St. Gall Priscian by R. Hofman and P. Moran: http://www.stgallpriscian.ie/, and of the oldest commentary tradition on Martianus Capella by M. Teeuwen: http://martianus.huygens.nl/path.

${ }^{3}$ For a general discussion of technical signs (which are commonly called also critical signs), see most recently A. TURA, "Essai sur les marginalia en tant que pratique et documents", in 'Scientia in margine': études sur les 'Marginalia' dans les manuscrits scientifiques du Moyen Âge à la Renaissance, ed. D. JACQUART and C. BuRnETT (Genève, 2005), pp. 261-387; M. STEIN, "Kritische Zeichen", Das Reallexikon für Antike und Christentum (Stuttgart, 2008), 133-163; and E. STEINOVÁ, "Notam Superponere Studui: The Use of Technical Signs in the Early Middle Ages" (unpublished doctoral thesis, Utrecht University, 2016).

${ }^{4}$ For the discussion of nota signs, see B. BISCHOFF, Latin Palaeography: Antiquity and the Middle Ages, trans. D. Ó CRÓINÍN and D. GANZ (Cambridge, 1990), pp. 172-173; M. MAniACI, Terminologia del libro manoscritto (Milano, 1996), p. 226; and R. Clemens and T. GRAHAM, Introduction to Manuscript Studies (Ithaca, 2007), p. 44. More recently, the evolution of the Latin nota sign has been treated in STEINOVÁ, “Notam Superponere Studui”, pp. 211-212.

${ }^{5}$ Some recent attempts include MAYR-HARTING, Church and Cosmos in Early Ottonian Germany; and H. SCHECK, "Reading Women at the Margins of Quedlinburg Codex 74”, in Nuns' Literacies in Medieval Europe: The Hull Dialogue, ed. V. BLANTON, V. O’MARA, and P. STOOP (Turnhout, 2013), pp. 3-18.
} 
mundane such as grammar, vocabulary or Greek terms? Could it be that in a single manuscript and even by a single hand, the nota signs were used in both capacities, and many more, but that this fact is beyond our grasp today? Should we not, therefore, restrain ourselves from trying to interpret technical signs to avoid the danger of imposing our own ideas and perspectives on the medieval material?

Indeed, technical signs do not tell us explicitly what was going on in the minds of their medieval users. Yet, this does not mean we cannot study them. On the contrary, I am convinced that they are a particularly fruitful area for modern research. Paleographers such as E.A. Lowe and Bernhard Bischoff were well-aware of the usefulness of technical signs for the understanding of the history of medieval books, even though they never produced monographs dedicated to them. ${ }^{6}$ Just as other paleographic and codicological features of the medieval book, technical signs can provide us with essential information about the origin and provenance of manuscripts, or they can offer a helpful complement to what we already know about them. In some cases, they can even be shown to be particular not only to regions or periods, but also to communities of manuscript users, scholarly circles or even notable individuals. ${ }^{7}$ In other cases, the presence of technical signs from one region in a manuscript produced in another can reveal a peregrinus or a visiting scholar or allow us to trace travelling books. ${ }^{8}$ Moreover, the presence of technical signs that were used only for specific tasks, such as excerption, can alert us to codices that were used by scholars, and that played a role in the composition of new texts or that attest to certain intellectual projects that we know about from other sources. ${ }^{9}$ Finally, technical signs are ubiquitous in early medieval Western manuscripts and thus allow for largescale studies that may be not possible for other types of marginalia or manuscript-related phenomena. Such large-scale studies, in turn, could reveal trends in early medieval book culture that would be

${ }^{6}$ This is evident from the fact that two types of technical signs, omissions and quotation marks, are systematically recorded in E.A. LowE, Codices Latini Antiquiores: A Palaeographical Guide to Latin Manuscripts prior to the Ninth Century, 11 vols. (Oxford, 1934-66). Lowe employed the data from the CLA to produce an article about the evolution of omission signs; E.A. LOwE, "The Oldest Omission Signs in Latin Manuscripts: Their Origin and Significance", in Miscellanea Giovanni Mercati (Vatican, 1946), IV, 36-79; reprinted in E.A. Lowe, Palaeographic Papers (Oxford: Clarendon Press, 1972), II, 349-380. A study of similar scope that explores the CLA data on quotation marks is currently in preparation by myself. Data from the second volume of the CLA were used by Patrick McGurk to produce a study on the use of quotation signs in the manuscripts from British and Irish libraries; P. MCGURK, "Citation Marks in Early Latin Manuscripts", Scriptorium 15:1 (1961), pp. 313. Bernhard Bischoff regularly refers to the presence of technical signs in his notes on ninth-century manuscripts now kept in the Bayerische Staatsbibliothek in Munich. Some of them made their way into his catalogue of ninth-century manuscripts; B. BISCHOFF, Katalog der festländischen Handschriften des neunten Jahrbunderts: (mit Ausnabme der wisigotischen), 3 vols. (Wiesbaden, 1998).

${ }^{7}$ An excellent example of technical signs used by a particular notable scholar are the annotations of Florus of Lyon; see C. Charlier, "Les manuscrits personnels de Florus de Lyon et son activité littéraire", in Mélanges E. Podechard (Lyon, 1945), pp. 71-85; reprinted in Revue Bénédictine (2009), pp. 252-267; and P. CHAMBERT-PROTAT, "Florus de Lyon, lecteur des Pères. Documentation et travaux patristiques dans l'Eglise de Lyon au neuvième siècle” (doctoral thesis, Paris, EPHE, in preparation).

8 An important category in this regard are late antique Italian codices preserved in Carolingian libraries and annotated by Carolingian users. Such codices can be in many cases discerned as travelling books on account of the presence of technical signs used typically in the Carolingian period but only inconsistently before, such as the characteristic S-shaped quotation marks; see for example CLA V 701, VI 763, VI 776 and VII 935.

${ }^{9}$ The presence of excerption signs in the form of Tironian hic and usque allowed David Ganz to identify manuscripts used by Ratramnus of Corbie for his theological treatises; see D. GANZ, Corbie in the Carolingian Renaissance (Sigmaringen, 1990), pp. 76-77. A new manuscript used by Ratramnus was identified on the basis of the same feature by Warren Pezé; see his article in the present volume CHECK PAGES. 
missed otherwise. ${ }^{10}$ These and other uses of technical signs, however, require first their systematic description, not with the aim of determining their specific meaning in particular manuscripts or their more generic function (although the latter is possible in some cases), but to understand their geographical and temporal distribution and to observe the patterns of their use by medieval annotators.

This, then, is also the aim of this article. More specifically, I shall provide a basic insight into the use of technical signs in manuscripts copied in Irish minuscule. ${ }^{11}$ In the first part, I describe twentythree technical signs employed in a set of manuscripts copied and annotated in Irish minuscule in the eighth and the ninth centuries. ${ }^{12}$ These are only a selection of all the surviving manuscripts produced in Irish minuscule in the period, but they allow us to reconstruct what may be termed the 'Irish standard', a pattern of the use of technical signs characteristic for annotators using Irish minuscule script. ${ }^{13} \mathrm{~A}$ different characteristic pattern of sign use has been shown to have existed among the users of Caroline minuscule, and in the second part of this paper I compare the 'Irish standard' with the 'Carolingian standard', pointing out some of the most important differences between the two that allow for a clear distinction between Irish and Carolingian annotating hands. ${ }^{14}$ Finally, in the third part of this paper, I focus on differences between the manuscripts selected for this study. For while it can be shown that there existed in the early medieval period a set of more general traits shared by manuscripts annotated in Irish context that distinguishes them from books annotated by Carolingian annotators, there are nevertheless some significant differences between individual codices annotated by hands using Irish minuscule that may be useful for identifying manuscripts belonging to particular Irish scholarly circles on the Continent.

This article is accompanied by three appendices. In Appendix I, I provide a description of the technical signs in each of the manuscripts selected for this study and samples of the signs described.

\footnotetext{
${ }^{10}$ We can, for example, observe a sharp rise in the use of quotation marks in Latin manuscripts between the sixth and the ninth centuries. I discuss this phenomenon in greater detail in the article I am preparing on the subject of quotation marks (cf. note 6).

11 While I am aware of the close relationship between the Irish and the Anglo-Saxon minuscule scripts and manuscripts produced in these scripts, I shall not discuss the annotation practices stemming from Anglo-Saxon book culture. I want to emphasise that I use the term Irish not in an exclusive fashion, meaning practices restricted to Irish minuscule environment, but simply to describe those phenomena that can be clearly associated with the use of Irish minuscule, irrespective of whether they also occur in the broader Insular manuscript culture. Some of the technical signs described below do not appear only in manuscripts copied or annotated in Irish minuscule and should be considered characteristic more broadly of the Insular scripts. I shall, therefore, use the term Insular when appropriate. I also do not specifically address the annotation practices in other Celtic areas such as Wales, Cornwall and Brittany, which had their own scribal culture affiliated with the Irish one. At least one annotator from the Celtic area outside Ireland is discussed here and shown to have used technical signs similar to the ones used by Irish annotators.

12 For the purpose of this study I classify any symbol recurring in a manuscript that follow a certain pattern as a technical sign. The criterion for considering a certain element a technical sign is not its function, as in many cases it is unclear what it was, nor how it was composed and how it looks (see footnote 28). On the contrary, I tended to include all the phenomena taking place in the margin, especially since they have commonly been neglected by modern scholars.

${ }^{13}$ In this article, I use the term Irish not to refer to books produced in Ireland, by scribes that are ethnically Irish, or in the sense of having to do with the Irish language. Rather, I use this term in the same fashion as it is used in 'Irish minuscule', i.e., to refer to a particular script and aspect of a book culture that had its origin in Ireland and that was exported to the British Isles and the Continent. Therefore, when I talk about the 'Irish standard' and the 'Irish mode of annotation', I refer to the practices of annotators who were trained to use this script, irrespectively of their location, ethnic background, or mother tongue.

14 The 'Carolingian standard' is described in STEINOVÁ, "Notam Superponere Studui”, pp. 221-250.
} 
Appendix II contains a comparative table of the most common sign forms encountered. Appendix III is a comparative table of the frequency of occurrence of particular signs.

\section{Manuscripts selected for this study}

The observations presented in this study are based on the examination of the layers of annotation in thirteen manuscripts produced in Irish minuscule script in the course of the eighth and the ninth centuries. In all cases these manuscripts are preserved in Continental libraries. Most of them either reached the Continent already during the early Middle Ages or were produced in Continental scriptoria by Irish scribes. ${ }^{15}$ They represent only a small selection of the total number of manuscripts produced in Irish minuscule script and associated with the Continent from the period. This selection was governed by the accessibility of the manuscripts, thus the manuscript studied here are those that were digitised or of which printed facsimiles were produced. As is clear from their place in W. M. Lindsay's Early Irish Minuscule Script and Bernhard Bischoffs 'Irische Schreiber im Karolingerreich', two seminal studies on early medieval Irish books on the Continent, they can be considered representative for the manuscripts produced in Irish minuscule in the period. They can be used to lay the basis for our understanding of the Irish practices of sign use in the early Middle Ages. ${ }^{16}$

The thirteen manuscripts discussed in this study can be divided into three groups. The first group consists of four manuscripts associated with the so-called Sedulius circle: three bilingual Graeco-Latin books of the Bible - St. Gallen, Stiftsbibliothek, MS 48 (second quarter of the ninth century; Continent, perhaps northern Italy; Gospels), Basel, Universitätsbibliothek, A VII 3 (third quarter of the ninth century; Continent; Psalms), and Dresden, Sächsische Landesbibliothek, A $145 \mathrm{~b}$ (second third of the ninth century; Continent; Pauline epistles) -, and the Bern Horace, Bern, Burgerbibliothek, MS 363 (third quarter of the ninth century; Continent). ${ }^{17}$ The manuscripts form a single group on account of the presence of a peculiar hand writing in Irish minuscule known as the Bern master. He made additions and marginalia in the three Graeco-Latin codices and copied the Bern Horace. ${ }^{18}$ Furthermore, in all four manuscripts, names of contemporary scholars and important individuals were entered in the margins together with a large number of technical signs. ${ }^{19}$ These are

\footnotetext{
15 The exception is Vatican, Biblioteca Apostolica Vaticana, Pal. Lat. 68, which was produced by Irish scribes working under English influence in northern England (see Appendix I, item 9). For the discussion of the mixed Anglo-Irish origin of the manuscript, see CLA I 78.

16 W.M. LINDSAY, Early Irish Minuscule Script (Oxford, 1910); B. BISCHOFF, "Irische Schreiber im Karolingerreich", in Jean Scot Erigene et l'bistoire de la philosophie (Paris, 1977), pp. 47-58; reprinted in B. BISCHOFF, Mittelalterliche Studien, 3 vols. (Stuttgart, 1981), III, pp. 39-54. Another important study of early Irish manuscripts that I refer to throughout this study is J.F. KENNEY, The Sources for the Early History of Ireland: an Introduction and Guide (Dublin, 1979).

${ }^{17}$ For the Sedulius circle, see KENNEY, The Sources for the Early History of Ireland, pp. 553-569; and W. BERSCHIN, GriechischLateinisches Mittelalter: von Hieronymus zu Nikolaus von Kues (Bern, 1980), pp. 175-176. Bern 363 is also treated in great detail in J. ContREnI, "The Irish in the Western Carolingian Empire (according to James F. Kennedy and Bern, Burgerbibliothek 363)", in Die Iren Und Europa Im Früheren Mittelalter, ed. H. LÖWE, 2 vols. (Stuttgart, 1982), II, 758-798; and S. GAVINELLI, "Per un'enciclopedia carolingia (Codice Bernese 363)", Italia medioevale e umanistica, 26 (1984), pp. 1-25. 18 This hand made additions in pp. 1-2 and 395 of St. Gallen 48, ff. Ir-v and 1b-11b of Dresden A 145b, and ff. 1v-3v and 98r-99v of Basel A VII 3. For the activity and identity of this Bern master, see the contribution of Giorgia Vocino in this volume CHECK PAGES.

${ }^{19}$ See Codex Bernensis 363 phototypice editus. Augustini de dialectica et de rhetorica libros, Bedae historiae ecclesiasticae librum I, Horatii carmina, Ovidii Metamorphoseon fragmenta, Servii et aliorum opera grammatica, cet. continens, ed. H. HAGEN (Leiden, 1897), pp. xliiilxviii. Of particular interest are the abundant references to two Irish scholars of the second half of the ninth century, Sedulius Scottus and John the Scot; see CONTRENI, "The Irish in the Western Carolingian Empire", pp. 768-798.
} 
the only technical signs found in manuscripts produced in Irish minuscule that were extensively described, albeit only separately for each manuscript. ${ }^{20}$

The second group consists of four manuscripts copied in Irish minuscule that were produced at an unidentified location in northern France, but kept from a certain point onward in Reichenau. Just as the manuscripts from the Sedulius group, the manuscripts from the Reichenau group form a coherent cluster because of the presence of the same copying and glossing hands. This group consists of Karlsruhe, Badische Landesbibliothek, Aug. Perg. 132 (mid-ninth century; northern France; Priscian), Karlsruhe, Badische Landesbibliothek, Aug. Perg. 167 (mid-ninth century; northern France; Bede), Karlsruhe, Badische Landesbibliothek, Aug. Perg. 195 (mid-ninth century; northern France; Augustine), and the so-called 'Reichenauer Schulheft', a quire from a lost manuscript affiliated with Karlsruhe 195, which is preserved today as a separate fascicle, St. Paul im Lavanttal, Stiftsbibliothek, MS 86b/1 (ninth century; prov.: Reichenau). ${ }^{21}$

The third set of manuscripts I studied is not a coherent group. It consists of the other manuscripts in Irish script that I could access, including four manuscripts produced on the Isles and brought to the Continent in the medieval times: Vatican, Biblioteca Apostolica Vaticana, Pal. Lat. 68 (eighth century; probably Northumbria; Commentary on Psalms), ${ }^{22}$ Würzburg, Universitätsbibliothek, M.p.th.f.12 (end of the eighth century; Ireland; Pauline epistles with an OldIrish gloss), ${ }^{23}$ Milan, Biblioteca Ambrosiana, C 301 inf. (end of the eighth or the beginning of the ninth century; Ireland; Commentary on Psalms), ${ }^{24}$ and St. Gallen, Stiftsbibliothek, MS 904 (c. 851 ; Ireland; Priscian). A fifth manuscript I also included is the Greek Psalter of Sedulius, Paris, Bibliothèque de 1'Arsenal, MS 8407 (third quarter of the ninth century; Continent). Even though it was copied mostly in Greek majuscule, it deserves a place in this study because of its potential affinity with the manuscripts from the Sedulius group. ${ }^{25}$ As can be seen from this overview, the last group is heterogeneous. I used it mostly to compare my observations on the two other groups. Because of the Insular origin of four of the manuscripts included in this group, moreover, it was also useful to see potential Carolingian influences on Irish annotation practices on the Continent.

\footnotetext{
20 See the prefaces of the facsimiles: H.C.M. RETTIG, Antiquissimus quatuor evangelicorum canonicorum codex Sangallensis GraeceLatinus (Turici, 1836), pp. xxviii-xlii; HAGEN, Codex Bernensis 363, pp. xxviii-xl; A. REICHARDT, Der Codex Boernerianus: der Briefe des Apostels Paulus (MSC. Dresd. A 145b) in Lichtdruck nachgebildet (Leipzig, 1909), p. 8; L. BIELER, Psalterium GraecoLatinum: codex Basiliensis A. VII. 3 (Amsterdam, 1960), pp. xi-xii. The signs in Bern 363 were also discussed separately in H. HAGEN, "Über die kritischen Zeichen der alten Berner Horaz- und Serviushandschrift cod. 363 saec. IX", Verhandlungen der Versammlung deutscher Philologen und Schulmänner in Zürich 39 (1888), pp. 146-147.

21 The latter manuscript is described in H.L.C. TRISTRAM, "Die irischen Gedichte im Reichenauer Schulheft", in Studia Celtica et Indogermanica. Festschrift für Wolfgang Meid zum 70. Geburtstag, ed. P. ANREITER and E. JEREM (Budapest, 1999), pp. 503-529.

${ }^{22}$ Technical signs used in this manuscript are discussed in M. MCNAMARA, "Introduction to Glossa in Psalmos: The HibernoLatin Gloss on the Psalms of Codex Palatinus Latinus 68”, in The Psalms in the Early Irish Church (Sheffield, 2000), pp. 17174. This manuscript was later kept at Lorsch; see both CLA I 78 and B. BISCHOFF, Die Abtei Lorsch im Spiegel ibrer Handschriften (Lorsch, 1989), p. 86, n. 98.

${ }^{23}$ Technical signs used in this manuscript are briefly discussed in L. STERN, Epistolae Beati Pauli glosatae glosa interlineali: Irischlateinischer Codex der Würzburger Universitätsbibliothek (Halle, 1910), p. xiv.

${ }^{24}$ Technical signs used in this manuscript are briefly discussed in R.I. BEST, The Commentary on the Psalms with Glosses in OldIrish Preserved in the Ambrosian Library (MS C 301 Inf.) (Dublin, 1936), pp. 29-30.

25 The Psalter was called after Sedulius Scottus because of the subscription on f. 55r, which reads: SH $\Delta$ YIOC . CKOTTOC . ЕГ . ЕГРАЧА ('I, Sedulius Scottus, have written this'). Kenney counts it among the manuscripts from the circle of Sedulius; see KENNEY, The Sources for the Early History of Ireland, p. 557.
} 


\section{Overview of technical signs used in Irish manuscripts}

In this section, I describe twenty-three technical signs that either occur consistently in the selected manuscripts or that occur only in two or three manuscripts, but are nevertheless relevant, either because they are characteristic of the Irish annotation practices or link the Irish manuscripts with manuscripts from other contexts of production. ${ }^{26}$

For understanding Carolingian Continental technical signs, we are helped with a number of texts in which their form and function are described. ${ }^{27}$ This is not the case for the signs used in the Irish context. In particular, we lack Irish sign treatises, i.e. technical lists that itemise various technical signs and provide their names, functions, and histories. The descriptions of Irish practices given here are thus entirely based on the analysis of the manuscripts themselves in which they are used and these do not reveal important details such as, for example, standardised names for certain signs, or, in the cases of sigla, what the single letters may abbreviate. ${ }^{28}$ Nevertheless, in some manuscripts, sigla alternate with fuller forms of words and these provide a clue to their meaning in this specific context and possibly also their broader functionality in the Irish annotation practices. Especially in cases where a siglum is resolved in the same word in multiple manuscripts, it seems safe to conclude that it had a shared meaning for Irish annotators in general. ${ }^{29}$ Moreover, in some cases it is possible to decipher the general function of technical signs by looking at the pattern of their use. If a certain sign consistently occurs next to passages that share a certain feature -e.g. Greek terms, corrections or errors in need of correction, or tituli-it seems reasonable to assume that this sign reflects that feature. Finally, while we possess no Irish sign treatises, some of the technical signs treated below are described in Continental sign treatises, which can be used to interpret them.

\footnotetext{
${ }^{26}$ While other signs also feature in the manuscripts, these are not discussed below, because they do not appear frequently enough and thus cannot be assessed; they occur only in a single manuscript, or it is unclear whether they have a purpose in the layers of annotation. I mention them, however, in Appendix I.

27 An important example of an early medieval sign treatise is the chapter De notis sententiarum in the Etymologiae of Isidore of Seville; see W.M. LINDSAY, Etymologiarum sive Originum libri XX, 2 vols. (Oxford, 1911), I, section 1.21. For the discussion of other Latin sign treatises, see H.D. JoCELYN, "The Annotations of M. Valerivs Probvs (II)", The Classical Quarterly 35:1 (1985), pp. 149-161.

28 It is important to point out here that technical signs could have been constructed in several distinct ways. They could be sigla, that is singular letters standing for a concept or operator by means of a standardised abbreviation; monograms, that is symbols produced by combining several letters into one that originally abbreviated a word, but which could have been understood as pure symbols (a good example are Greek monograms, which were used in the Latin West without the necessary understanding of the Greek they abbreviated); graphic symbols representing simplified depictions of objects or concepts (for example the star-shaped asteriscus and the dagger-like obelus); or simpler graphic elements such as dots, crosses and slashes, to which meaning was attributed by a common agreement. Of these four forms, Irish annotators seem to have favoured sigla. This is evident especially from the comparison with manuscripts annotated in Carolingian environment, where sigla were also used, but other forms of technical signs were more common than in manuscripts copied in Irish minuscule. The sigla are a somewhat ambiguous category of technical signs because their users often use them side by side with full and abbreviated word forms for the same concept, which cannot be considered technical signs. I consider them equivalent with other technical signs as far as they can be shown to reflect a standardised practice, especially if they appear in multiple manuscripts and thus point to a certain community of users and a convention of use shared by this community; see STEINOVÁ, “Notam Superponere Studui”, pp. 4-7.

${ }^{29}$ However, it should not be presumed that if the same letter appears as a siglum in multiple manuscripts it has the same function or meaning, since it may encode different words or concepts beginning with the same letter. For example, the letter q could stand for quare as much as for quaestio and letter f can stand for finit, fabula or formula.
} 
In this section, I first describe thirteen technical signs that seem more common: they appear in at least four of the manuscripts from the set. Their frequency of use is such that they can be considered characteristic for Irish manuscripts. They provide us with a basic comprehension of Irish annotation practices. Second, I discuss ten additional technical signs that do not appear in more than three manuscripts from the set. Their distribution patterns are less regular, but they are still considered here because they appear in large quantities in a small number of manuscripts, because we can grasp their function, because they are known from Continental sign treatises, or because they are of special interest for understanding Irish annotation practices. I ordered the items below according to their frequency, starting with the most common sign and ending with the rarest one.

\section{The most common signs used in early medieval manuscripts copied in Irish minuscule}

lege: a symbol that has the form of the Irish minuscule letter 1 or an 1 with the shaft crossed is the only technical sign which is present both consistently and persistently in the manuscript set selected for this study: it features in eleven out of the thirteen manuscripts, and in all cases annotates at least $8 \%$ of the pages in the manuscript (in the Graeco-Latin Psalter, Basel A VII 3, it even occurs in $42.5 \%$ of the pages)..$^{30}$ The siglum can be resolved as lege, a word which can be encountered in full in several of the manuscripts. ${ }^{31}$ Because of the frequency and pattern of use, it can be interpreted as an attention sign indicating passages of interest and cross-references. In this regard, it may hold a similar place in the early medieval Irish annotation practices as nota signs had in Carolingian Continental practices. This lege siglum should not be confused with several similar-looking signs: the l-shaped sign that marks liturgical lessons in some manuscripts and the nel abbreviation that was commonly used in the early Middle Ages to indicate variant readings. ${ }^{32}$
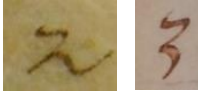

$\zeta \boldsymbol{\eta} \boldsymbol{\varepsilon} \tilde{\mathbf{\varepsilon}}$ : the second most common Irish technical sign is a symbol that has the form of the minuscule letter $z$ (or Greek letter $\zeta \dot{\eta} \tau \alpha$ ). It occurs in seven manuscripts (or nine, if manuscripts which contain this sign only once or twice are considered), although in only one of the manuscripts it appears in more than $10 \%$ of the pages (Dresden A 145b, 31\%). ${ }^{33}$ This distribution pattern indicates a sign that was fairly standard, but used only infrequently and rarely in a systematic fashion. The zshaped siglum is known from other manuscript contexts, such as ancient papyri and late antique

\footnotetext{
${ }^{30}$ All reference to the percentages of pages covered by a particular sign are made to Appendix III. The absolute numbers of pages containing signs are made to Appendix II.

${ }^{31}$ In St. Gallen 48, the note Martianum lege is found in p. 155. In Basel A VII 3, the same command appears in notes Genesin lege (f. 61r) and lege titulos canticorum (f. 63v). In St. Gallen 904, it appears only as lege (p. 26). However, the fully written form of this command features most notably in Bern 363, in which it appears both as lege (ff. 21r, 85r, 89v and 135v) and as a part of longer notes (bic lege on f. 36v, lege semper on f. 37v, semper lege on f. 42v, incipe lege on $\mathrm{f} .53 \mathrm{v}$, and honoratum lege on $\mathrm{f}$. $83 \mathrm{v})$.

32 For technical signs used for marking liturgical lessons, see C. VOGEL, Medieval Liturgy: An Introduction to the Sources (Washington, D.C., 1986), pp. 315-316. Vogel does not explicitly mention the 1-shaped lectio signs; however, they are mentioned, for example, in E. Rose, "Virtutes Apostolorum: Origin, Aim, and Use", Traditio 68 (2013), p. 142.

${ }_{33}$ Moreover, $\zeta \eta \tau \varepsilon \tilde{~}$ seems to have been the preferred correction sing of the Bern master in his additions in St. Gallen 48, Basel A VII 3 and Dresden A 145b (see Appendix IIIb). He used it in all of these additions, unlike require, which appears only in Bern 363 (see also footnote 52).
} 
codices, in which it functioned as a query sign. ${ }^{34}$ The siglum probably abbreviates a form of the Greek

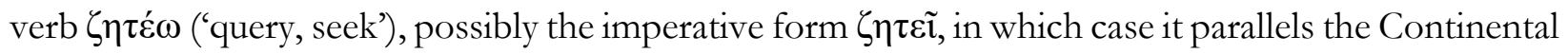
require correction sign (see below). Two pieces of manuscript evidence confirm that the z-shaped sign and require had the same function. First, in four of the manuscripts, it is used for the same passages as

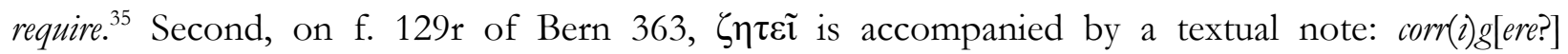
nec[essarium?].

cross: the cross is one of the most common signs in manuscript margins throughout the entire Middle Ages. While it may have a specific Christian connotation in some cases, in most cases it has not. ${ }^{36}$ In the manuscripts examined here, the cross is the third most common technical sign, appearing in six out of the thirteen manuscripts, in one case on more than two thirds of the pages of the manuscript (Pal. Lat. 68, 68.5\%). It does not seem to have had a single function. In Pal. Lat. 68 (Commentary on Psalms) and Karlsruhe 132 (Priscian), crosses mark the beginning of new sections. In Karlsruhe 195 (Augustine), twelve crosses added by a second hand appear in a sequence that could mark lessons (ff. 13r-17r). ${ }^{37}$ In three other cases, no obvious pattern can be recognized. ${ }^{38}$

Insular quotation sign: in five of the manuscripts examined, quotations from authoritative texts (Virgil, Ovid, Bible, etc.) are marked with a symbol that consists of one or two dots and a slash. This quotation sign is attested also in Anglo-Saxon manuscripts and it may be considered the characteristic Insular form of a quotation mark (although we will see that the manuscripts also contain another type of quotation sign adopted from Greek book culture). ${ }^{39}$ The Insular quotation sign is regularly used for each citation in a manuscript. In this regard, it can be contrasted with the $\zeta \eta \tau \varepsilon \tilde{\imath}$ query sign: the query sign occurs in more manuscripts, but always inconsistently and in small quantities, whereas the Insular quotation signs appear in fewer manuscripts, but are usually employed systematically.

${ }_{34}$ W.M. LINDSAY, Palaeographia Latina (London, 1923), II, pp. 11-12; A.C. ClARK, The Acts of the Apostles (Oxford, 1933), pp. 371-373; and E. TuRNER, Greek. Manuscripts of the Ancient World (London, 1987), p. 16.

35 In St. Gallen 48 on p. 365, in Bern 363 on pp. 17v, 20r and 80v, in Dresden A 145b on f. 93v, and in Basel A VII 3 on f. $76 \mathrm{v}$.

${ }^{36}$ Crosses have been used as technical signs already in Classical Antiquity as is clear from the evidence of papyri; see K. MCNAMEE, Sigla and Select Marginalia in Greek. Literary Papyri (Bruxelles, 1992), p. 38.

${ }^{37}$ For crosses used as lesson marks in Insular context, see CLA II 150, 194a, 213 and 260.

38 Although it can be noted that in Karlsruhe 167 (Bede), two crosses added by the main hand mark the beginning of a section, while a third cross added by a secondary hand does not. In general, the crosses added by main hands are often text-structuring, while at least some of secondarily added crosses seem to function rather as attention signs; see TURA, "Essai sur les marginalia", pp. 275-276.

39 The graphic form of this sign probably originated as a corrupt or a cursive form of the diple (see below) and it is thus genetically related to the S-shaped quotation sign used on the Continent, which originated in the same fashion; see MCGURK, "Citation Marks in Early Latin Manuscripts", p. 7. In some cases, the transformation of the diple can be already observed in manuscripts from the sixth century and at least in one sixth-century manuscript, El Escorial, Camarin de las Reliquias, MS s.n. ( $7^{\text {th }}$ century, in.) one can see a form of the quotation sign that resembles the Insular quotation sign; see CLA XI 1629. 
trigon: ${ }^{40}$ a sign in the form of a triangle of dots appears in larger numbers in four manuscripts, most prominently in Würzburg M.p.th.f. 12 (twenty times, which is on 28\% of the pages) and Milan C 301 inf. (twenty-one times, which is on 7\% of the pages). If manuscripts in which the sign appears only once or twice are included, it is one of the more common technical signs used by Irish annotators, occurring in eight manuscripts (but only in one manuscript from the Sedulius group). It seems safe to conclude that its pattern of use resembles that of the $\zeta \eta \tau \varepsilon \tilde{i}$ sign: it is used in many manuscripts, but usually only in a few instances. Triga also appear in manuscripts from the Carolingian context. ${ }^{41}$ The manuscripts provide no clue as to the function of this sign. It is probable that it served to mark passages of interest, although it is unclear whether it had a more subtle meaning beyond that.

c-shaped sign: the four manuscripts belonging to the Sedulius group contain a sign that has the form of the minuscule letter c (sometimes with a dot, sometimes without). A c-shaped sign appears also five times in the last twenty-five folia of St. Gallen 904. The function of this sign is unclear. It is plausible that the siglum has the same function in the manuscripts from the Sedulius group (of which Dresden A 145b contains the most c's: in 30\% of its pages), but perhaps not in St. Gallen 904. In Bern 363 , it is commonly combined with the siglum s (see below). ${ }^{42}$ In this manuscript, one can also find marginalia that read cor s or cor semper (e.g. on ff. 41r, 137v, and 145r) and on f. 65r one can read Cormac semper. It should be, however, not taken for granted that the c's and cor's in Bern 363 refer to the same entity. While cor's may, indeed, represent a personal name (such as Cormac), to use c's in this fashion would be an extraordinary case of abbreviation that goes against other patterns in the manuscripts from the Sedulius group. ${ }^{43}$ A possible explanation of this siglum (but obviously not of cor) is a form of the verbs contemplare or considerare. ${ }^{44}$

\footnotetext{
${ }^{40}$ I take the name trigon from the neume of the same shape; see "Neumes", in Harvard Dictionary of Music, ed. W. APEL (Harvard, 1969), pp. 571-572. The same symbol was used in Insular manuscripts also as a punctuation sign; see P. SAENGER, Space Between Words: The Origins of Silent Reading (Stanford, CA, 1997), p. 73.

${ }^{41}$ Some examples include Paris, Bibliothèque nationale de France, Lat. 12239 ( $8^{\text {th }}$ century, Corbie), Amiens, Bibliothèque municipale, MS 220 ( $8^{\text {th }}$ century, ex., Corbie), St. Gallen, Stiftsbibliothek, MS 87 (9th century, in., St. Gallen), Leiden, Universiteitsbibliotheek, Voss. Lat. F 30 (c. 825, northwestern Germany), and Milan, Biblioteca

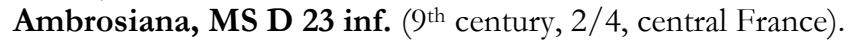

${ }^{42}$ This combination occurs also in the additions made by the Bern master in St. Gallen 48, Basel A VII 3, and Dresden A 145b (see Appendix IIIb).

${ }^{43}$ Even in the richly annotated Bern 363, the names of contemporary scholars given in the margins are never abbreviated beyond two letters, e.g. Ag for Agano. The most common form of abbreviation has three letters (thus $S e d$ for Sedulius and Iob for John the Scot), which could support the resolution of cor as Cormac, but not of the c. By contrast, marginalia that do not refer to persons are commonly abbreviated to a single letter, such as in the case of lege or $\zeta \eta \tau \varepsilon \tilde{i}$. Moreover, while c's appear commonly in all manuscripts from the Sedulius group, names appear in larger numbers only in Bern 363 (see Appendix I) and thus this explanation of the c-shaped sign does not fit well with their annotation pattern. Notably, Dresden A $145 \mathrm{~b}$ contains only seven references to contemporary personages, but no less than 59 pages are annotated with the cshaped sign.

${ }^{44}$ Herman Hagen observes that the sign is attached to passages that omnes vel argumenti quodam pondere vel rerum ibi tractatarum novitate insignes sunt, see HAGEN, Codex Bernensis 363, p. xxxviii. A third option would be to consider both the c-shaped signs and $c o r$ 's to stand for corrige. This interpretation would fit both forms found in Bern 363; however, even this interpretation is problematic: early medieval Irish annotators used two other signs to mark passages in need of correction -the $\zeta \eta \tau \varepsilon \tilde{~}$ query sign and require correction sign (see below) - and thus to use a third one seems superficial.
} 
o-shaped sign: a sign in the form of the minuscule letter o appears in five manuscripts: the four manuscripts that constitute the Reichenau group (ranging in the frequency of occurrence in these manuscripts from 8\% to 19\%) and St. Gallen 904, in which it appears on $63 \%$ of the pages. It is one of the signs of which the function cannot be ascertained on the basis of its pattern of use alone. Nevertheless, it can be noted that this sign and the lege sign are the two sigla that appear consistently in all manuscripts from the Reichenau group. At the same time, the o-sign appears in none of the manuscripts from the Sedulius group.

r

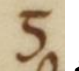

graecum: a symbol that has the shape of the Greek letter $\gamma \dot{\alpha} \mu \mu \alpha(\Gamma)$ or, less frequently, of the Irish minuscule letter $g$ appears in the four manuscripts from the Sedulius group and in St. Gallen $904 .{ }^{45}$ In the manuscripts from the Sedulius group, it is used consistently, occurring on between 6\% (49 occurrences, St. Gallen 48) and 51.5\% (103 occurrences, Basel A VII 3) of the pages, while in St. Gallen 904, it occurs on 3\% of pages (7 occurrences). Basel A VII 3 provides an important clue to the function of this sign: in twenty-one cases, signs are accompanied by textual notes connecting a particular Greek word in the same line of the main text with a derived Latin word familiar to the annotators or glossing the word in Latin (see Appendix I, item 2). The word abbreviated by this siglum is most likely graecum, i.e. the sign marks interesting Greek vocabulary. ${ }^{46}$

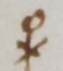

chresimon: one of several technical signs that feature only in the four manuscripts from the Sedulius group is a monogram consisting of the Greek letters chi and rbo (X and P). ${ }^{47}$ This sign is described in several early medieval sign treatises as an all-purpose attention sign and its use in this

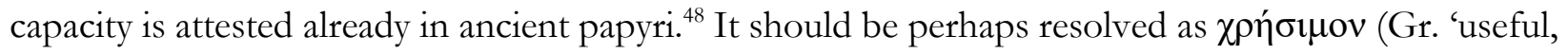
beneficial'). ${ }^{49}$ In the manuscripts from the Sedulius group, chresimon is indeed used as an attention sign. It is particularly prominent in Bern 363, in which it appears 172 times (on 44\% of the pages), four times with a textual note explicitly indicating a point of interest. ${ }^{50}$

\footnotetext{
${ }^{45}$ With regards to its graphic form, the shape of this siglum resembles the sign of paragraphus, which was used in the early medieval period to mark the beginnings of new sections or excerpted passages. Cf. the description of this sign in Isidore, Etym. 1.21.8: Paragraphus ponitur ad separandas res a rebus, quae in conexu concurrunt, quemadmodum in Catalogo loca a locis et [regiones a] regionibus, in Agone praemia a praemiis, certamina a diversis certaminibus separantur. However, it should not be conflated with this sign. The g-shaped variant appears once in Basel A VII 3 (on fol. 52r) and twice in St. Gallen 904 (on pp. 146 and 187).

${ }^{46}$ For more elaborated analysis of the use of this sign, see Pádraic Moran, 'Greek Dialectology and the Irish Origin Story', in Early Medieval Ireland and Europe: Chronology, Contacts, Scholarship. A Festschrift for Dáibhi Ó Cróinín, ed. by Pádraic Moran and Immo Warntjes, Studia Traditionis Theologiae, 14 (Turnhout: Brepols, 2015), pp. 481-513 (pp. 499-500).

${ }^{47}$ Chresimon also appears three times in St. Gallen 904 (pp. 137, 138, and 227), but it seems to function as a signe de renvoi in two of these cases (see below).

48 See MCNAMEE, Sigla and Select Marginalia, pp. 45-47.

${ }^{49}$ It should not be, thus, confused with the Christogram, which was used in iconography and in charters as a symbol of Christ.

${ }^{50}$ In $\mathrm{f} .34 \mathrm{v}$ with de medicina, on $\mathrm{f} .95 \mathrm{v}$ with de insola creta, on $\mathrm{f} .104 \mathrm{v}$ with de flexu genuum ut scotti faciunt, and on $\mathrm{f} .191 \mathrm{r}$ with de scottorum fide.
} 
require: another technical signs that appears only in the four manuscripts from the Sedulius group is a siglum in the shape of letter $\mathrm{r}$ (resembling a Carolingian minuscule $\mathrm{r}$ rather than an Irish one). ${ }^{51}$ This sign is known from contemporary Carolingian manuscripts, in which it stands for require and serves as a correction sign. Indeed, this seems to be its function also in the manuscripts from the Sedulius group. In fact, in three of these manuscripts, it is the most frequently used correction sign, appearing 104 times in Bern 363 (on 26\% of the pages), ninety-nine times in St. Gallen 48 (12.5\%), and seventy-three times in Basel A VII 3 (37\%). ${ }^{52}$ Only in Dresden A 145b the primary correction sign is $\zeta \eta \tau \tilde{\mathbf{u}}$, which occurs sixty-two times in this manuscript (on $31 \%$ of the pages), while require was employed a supplementary correction sign in six pages $(3 \%){ }^{53}$

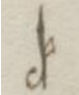

deest: in the manuscripts studied here, omissions are supplied by means of a pair of omission signs: $\mathrm{d}$ (for deest) and $\mathrm{h}$ (for hic?, see Appendix I). The former is placed in the main text window where something is missing and the latter in the margin with the words filling in the lacuna. ${ }^{54}$ In the four manuscripts from the Sedulius group, however, the d-shaped sign appears sometimes without a complement. ${ }^{55}$ In these cases, it also stands for deest as is clear from the fact that it is sometimes written as $d e \div(\div$ being a standard Insular abbreviation for est, see on pp. 390 and 393 in St. Gallen 48 and f. 30r of Bern 363) and once even in full (on f. 28r of Bern 363). Moreover, it regularly appears next to blanks in the main text (e.g. on f. 49r of Basel A VII 3, 62v of Dresden A $145 \mathrm{~b}$, or $7 \mathrm{r}$ of Bern 363) or next to passages filled in by a second hand (e.g. on f. $85 \mathrm{r}$ of Basel A VII 3 or p. 159 of St. Gallen 48). This indicates that the $\mathrm{d}$ and $\mathrm{h}$ omission signs were not used simultaneously, but rather that the d's were first added next to a lacuna and the missing material was added once a second source was identified. ${ }^{56}$ In cases where no suitable material was found, the passages were left marked with d's. ${ }^{57} \mathrm{~A}$ d-shaped symbol with dots on both sides (.d.) also appears in seven pages of Karlsruhe 195, but here they are certainly not deest signs, as is clear from glosses that appear above the words in these lines in several cases (id est.d.). Possibly, the siglum here abbreviates the word definitio.

51 The Irish minuscule $r$ is used in the same fashion only once, on p. 328 of St. Gallen 48.

52 The comparison of Bern 363 with the additions made by the Bern master in the other three manuscripts from the Sedulius group (Appendix IIIb), however, suggests that the preferred form of the correction sign of the Bern master was not require but $\zeta \eta \tau \varepsilon \tilde{i}$, which is the only technical sign this annotator used consistently in all four cases (while require appears

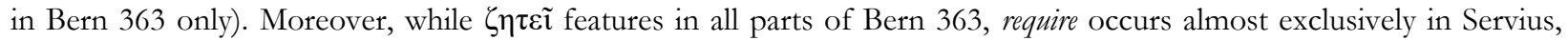
which could suggest that this correction sign was copied from a (Continental) prototype just like other signs (see Appendix I, item 4).

${ }^{53} \mathrm{By}$ contrast, require is the primary and $\zeta \eta \tau \varepsilon \tilde{\mathrm{i}}$ a supplementary correction sign in the other manuscripts, appearing thirtytwo times in Bern 363 (8\% of pages), twelve times in St. Gallen $48(\sim 1.5 \%)$ and three times in Basel A VII 3 ( $1.5 \%$ ).

${ }^{54}$ However, Lowe explicitly calls it an Anglo-Saxon rather than an Irish Insular feature; see Lowe, "The Oldest Omission Signs", p. 76. My manuscript set does not confirm Lowe's observation.

55 It appears ten times in St. Gallen 48 (1\%), seven times in Basel A VII 3 (3.5\%), five times in Bern 363 (1\%), and three times in Dresden A $145 \mathrm{~b}(1.5 \%)$.

56 See E. KWAKKEL, "Behind the Scenes of a Revision: Michael Scot and the Oldest Manuscript of His Abbreviatio Avicenne", Viator 40:1 (2009), p. 113.

${ }^{57}$ A fifth manuscript that may contain this sign is St. Gallen 904, in which d features thirteen times, but only once has the form of deest (de $\div$ in p. 96). The twelve other signs look unlike the deest and may be signes de renvoi of the kind appearing throughout this copy of Priscian (see below). 
quaestio: a sign in the form of the minuscule letter $\mathrm{q}$ or a $\mathrm{q}$ with its shaft crossed features in four manuscripts examined in this study. Three of them - St. Gallen 48, Bern 363, and Dresden A 145b - belong to the Sedulius group. The fourth is St. Gallen 904, in which this sign has the form of majuscule $Q$ with a crossed shaft (28\% of the pages) ${ }^{58}$ In Bern 363, it is the most frequently occurring sign: it appears on $74 \%$ of the pages. ${ }^{59}$ Bern 363 also offers a clue to the function of this sign, which seems to represent the word quaestio, written in full on ff. 31r (quaestio comgan), 35v (quaestio + qstio), and 80r (qstio). In this manuscript and in St. Gallen 48, quaestio signs are often combined with marginalia containing the names of persons typical for the Sedulius group. ${ }^{60}$

\section{u}

uersus: a sign in the form of minuscule letter $\mathrm{u}$ or $\mathrm{v}$ is found in four of the manuscripts. In St. Gallen 904, it appears 160 times (67\% of the pages), being the most frequently used technical signs in this manuscript. It also features in two manuscripts from the Reichenau group (in Karlsruhe 132 in 12.5\% of the pages and in the 'Reichenauer Schulheft' once) and in Bern 363 from the Sedulius group ( $9 \%$ of the pages). The function of this technical signs can be gleaned from several instances when it is written as uers (St. Gallen 904, p. 146) and uersus (Bern 363, ff. 83r and 138v). Indeed, the sign is placed regularly next to verses cited in the manuscript texts and in St. Gallen 904, the sign is often furnished with the tags gor (for Georgics) and $b o$ (for Bucolics) to indicate the works referred to. The sign is found once in Milan C 301 inf. (f. 74r) and in Basel A VII 3 (f. 24v), but here its function remains unclear.

\section{Technical signs used less frequently in early medieval manuscripts copied in Irish minuscule}
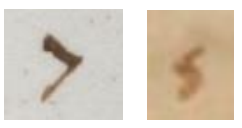

diple: two manuscripts feature technical sign resembling a modern 'greater-than' symbol, called diple (from Greek $\delta \imath \pi \lambda \tilde{\eta}$, 'double') in sign treatises. ${ }^{61}$ In these, the sign is described as a quotation sign and this is indeed its function in the manuscripts studied here. ${ }^{62}$ The two manuscripts are both Graeco-Latin New Testament codices (St. Gallen 48 containing the Gospels and Dresden A

\footnotetext{
${ }^{58}$ Franck Cinato and Padraic Moran suggested to me that this sign might not represent the letter Q but rather a crossed variant of the o-shaped sign, a technical sign that is otherwise very prominent in this manuscript (see above). Indeed, the cross seems to have been added to some of the signs, for example on p. 131.

${ }_{59}$ Although it should be noted that it features almost exclusively in the first cluster of text in this manuscript, Servius's commentaries (see Appendix I, item 4).

${ }^{60}$ In St. Gallen 48, quaestio is linked with the names $A \triangle A \Lambda$ (berga?) on p. 79, $A \Gamma A($ no $)$ on p. 104, and Dub(thach?) on p. 388. In Bern 363, it appears regularly with the names of Sedulius and Iohannes, but also once with Comgan (f. 31r), once with Dub(thach?, f. 38r), once with Fergus (f. 127r), twice with Agano (ff. 95r and 87v), and five times with Dodo (ff. 55v, 70r, 74v, $78 \mathrm{v}$, and $79 \mathrm{v})$.

${ }^{61}$ Isidore, Etym. 1.21.13: Diple. Hanc scriptores nostri adponunt in libris ecclesiasticorum virorum ad separanda vel [ad] demonstranda testimonia sanctarum Scripturarum. Other sign treatises mentioning diple include the Anecdoton Parisinum, the Anecdoton Romanum and the Anecdoton Venetum; see A. GudemAn, "Kritische Zeichen", Paulys Real-Encyclopädie der classischen Altertumswissenschaft (Stuttgart, 1922), pp. 1917-1918. An s-shaped symbol also appears in St. Gallen 904 (on 9.5\% of pages), but does not seem to be employed as a quotation sign (see Appendix I, item 12).

${ }^{62}$ Both Parkes and Saenger consider diple more broadly an Insular feature; M.B. PARKES, Pause and Effect: An Introduction to the History of Punctuation in the West (Aldershot, 1992), p. 27; SAENGER, Space Between Words, p. 74.
} 
145b containing the Pauline epistles), in which Old Testament references are marked in this fashion. The presence of Greek explains the use of diple rather than the standard Insular quotation signs as diple is a typical Greek quotation sign. ${ }^{63}$ This perhaps also explains the presence of diple-like signs in Paris Arsenal 8407, the Greek Psalter of Sedulius, in which they appear on 19\% of the pages. However, the sign does not mark biblical quotations here. The diplai in this manuscript appear both in the standard form (e.g. on f. $49 \mathrm{v}$ ) and in the 'cursive' form, resembling the modern letter s (e.g. on f. $42 \mathrm{v}$ ). ${ }^{64}$

m-shaped sign: three of the manuscripts from the set contain a siglum in the form of the Greek letter $\mu \tilde{v}$ (written in Irish minuscule as $\mathcal{\Upsilon}$ ). In only one manuscript it occurs more consistently: Pal. Lat. 68 (in 23\% of the pages). Here it can be resolved as moraliter on account of the variant For on f. 38v. ${ }^{65}$ In the two other manuscripts, St. Gallen 904 and Milan C 301 inf., it appears only a handful of times (five times in the former, three times in the latter) and its function is unclear. Nevertheless, it can be pointed out that the sign features only in manuscripts produced on the Isles. A siglum in the form of the majuscule letter $\mathrm{M}$, which may be a graphic version of $\mathcal{C}$, occurs in two more manuscripts - five times in Karlsruhe 167 and six times in St. Gallen 48. ${ }^{66}$ However, again there is no clue in these manuscripts to interpret its function. These $\mathcal{- C}$ - and $\mathrm{M}$-shaped signs should not be confused with a similar-looking sign that is used for magister (or $\mu \alpha \theta \eta \tau \dot{\eta} \varsigma$, Gr. 'pupil') in texts that have the form of a dialogue, both in Insular and in Continental manuscripts. ${ }^{67}$
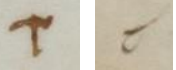

t-shaped sign: in St. Gallen 48, 34 pages (4\% of the manuscript) were annotated with a sign in the shape of a capital letter $\mathrm{T}$ (or Greek letter $\tau \alpha u$ ). The function of this sign is not clear, although it may mark the beginning of new episodes, as it occurs frequently next to a Greek chapter number and title. A T-shaped sign occurs seven times also in the second half of Bern 363 and a sign in the form of minuscule $t$ is found in St. Gallen 904 (twelve times, on 5\% of the pages). It is unclear what the function of this siglum in these manuscripts is.

two dots: three manuscripts from the set - Milan C 301 inf. (12\% of pages), Karlsruhe 132 (3\% of pages), and St. Gallen $904(2 \%)$ - contain a sign in the form of two horizontally aligned dots. Its function is unclear. Perhaps, it is a variant of the trigon and thus an attention sign.

\footnotetext{
63 They can be found, for example, in two ninth-century manuscript of the Orationes of Gregory of Nazianzus, Milan, Biblioteca Ambrosiana, E 49-50 inf. and Paris, Bibliothèque nationale de France, Gr. 510. The latter manuscript is digitised at: http://gallica.bnf.fr/ark:/12148/btv1b84522082/f60.item (a sequence of diplai can be seen on f. 23v). See also MCGURK, "Citation Marks in Early Latin Manuscripts”, p. 4.

${ }^{64}$ For the transformation of the ancient diple into a cursive form, see LINDSAY, Palaeographia Latina, p. 19.

${ }^{65}$ See also MCNAmARA, "Introduction to Glossa in Psalmos", p. 173. Moreover, the same manuscript, a commentary on the Psalms, also contains another siglum that may refer to the four-fold interpretation of the Bible: $h$ which possibly stands for historialiter (unless it is a source mark for bieronymus).

66 An M-shaped sign appears also in some of the pre-800 manuscripts. It can be found, for example, in Bologna, Biblioteca Universitaria, MS 701 ( $5^{\text {th }}$ century, 2/2, southern or central Italy), where it stands for mire, a common exclamation found in Late Antique codices; see CLA III 280.

${ }^{67}$ For description of this practice as well as the confusion between the Greek and Latin use of 'teacher' and 'pupil' markers, see J. O’DONNELL, Cassiodorus (Berkeley, CA, 1979), pp. 247-248; and W. BERSCHIN, Griechisch-Lateinisches Mittelalter: von Hieronymus zu Nikolaus von Kues (Bern, 1980), p. 125.
} 
fabula: a siglum in the form of the minuscule letter $\mathrm{f}$ appears more than a hundred times in the first part of Bern 363 containing the commentaries of Servius (in $32 \%$ of all the pages, or in $44 \%$ of the Servius part). This siglum alternates with the abbreviated form fab and on $\mathrm{f} .36 \mathrm{v}$ it is even written in full as fabula. It marks passages containing mythological material. The same marker (in the form fab) can be also encountered in other manuscripts of Servius's commentaries. ${ }^{68}$ In this regard, it is likely that it is a feature of the annotation tradition of Servius taken over from the prototype of Bern 363 rather than an Irish technical sign. ${ }^{69}$ It is far less clear what the function of this siglum is in three other manuscripts: we find it twice in Basel A VII 3 and St. Gallen 904, and once in Karlsruhe 132. These signs perhaps reflect a Continental practice, such as that of using the finit siglum to mark the ends of sections. ${ }^{70}$

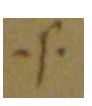

semper: Bern 363 also contains fifty-five times a siglum in the shape of minuscule letter $\mathrm{s}(14 \%$ of the pages). This technical signs is regularly paired with the siglum c $(c s)$ and it is also found in this manuscript as cor semp (e.g. on ff. $137 \mathrm{v}$ and 145r), which suggests that $s$ stands for semper. In ff. 150r and 152r, the siglum is combined with what seems to be a reference to a person: $s d r u$. In St. Gallen 904, s-shaped siglum appears in seven pages (3\% of the pages), and in Basel A VII 3 it appears twice. It is unclear whether it stands for semper in these manuscripts. It should be noted that an AngloSaxon convention of excerption marks makes use of sigla s (for scribe) and d (for dimitte), but the Irish and the Anglo-Saxon practices should not be conflated. ${ }^{71}$

$\mathcal{E}$

cryphia: a symbol that looks like a lower half of the circle with a dot in the centre was used since Late Antiquity as a correction sign in Latin manuscripts. ${ }^{72}$ Isidore of Seville calls it a cryphia. ${ }^{73}$ This technical sign features prominently in St. Gallen 904, in which it occurs on 21\% of the pages,

${ }^{68}$ For example in Leiden, Universiteitbibliotheek, BPL 52 ( $8^{\text {th }} / 9^{\text {th }}$ century, Corbie). See F. WORMALD and G.I. LIEFTINCK, Servii Grammatici in Vergilii carmina commentarii: Codex Leidensis B.P.L. 52 (Amsterdam, 1960).

${ }^{69}$ For layers of annotation taken over by the Bern master from his prototypes, see also VOCINO in this volume. CHECK PAGES

70 The finit sigla can be seen, for example, in Trier, Stadtbibliothek, MS $22\left(8^{\text {th }} / 9^{\text {th }}\right.$ century, royal court; CLA IX 1366), on $\mathrm{f} .137 \mathrm{r}$ of Paris, Bibliothèque nationale de France, Lat. 13386 ( $9^{\text {th }}$ century, 3/4, Brittany), and on ff. 149r-150r of Vatican, Bibliotheca Apostolica Vaticana, Ottob. Lat. 313 ( $9^{\text {th }}$ century, France). The signs in the Paris manuscript can be seen at: http://gallica.bnf.fr/ark:/12148/btv1b10525100r/f279.item. See also W. PEZÉ, “Le virus de l'erreur: Essai d'histoire sociale sur la controverse prédestinatienne à l'époque carolingienne" (unpublished doctoral thesis, Université Paris I Panthéon - Sorbonne, 2014), p. 607.

${ }^{71}$ See B. BISCHOFF, “Aus Alkuins Erdentagen”, in Mittelalterliche Studien (Stuttgart, 1967), II, p. 17.

${ }^{72}$ See STEINOVÁ, "Notam Superponere Studui”, pp. 208-209. A notable example of a late antique cryphia can be found in the Ravenna Orosius, Florence, Biblioteca Medicea Laurenziana, Plut. 65.1 (6 $6^{\text {th }}$ century, probably Ravenna), f. 35v, where a margin note accompanying the symbol reads: Non est sensus in boc loco. See the digital image at: http://teca.bmlonline.it/ImageViewer/servlet/ImageViewer?idr=TECA0000767441\#page/1/mode/1up.

${ }^{73}$ Isidore, Etym. 1.21.10: Cryphia, circuli pars inferior cum puncto, ponitur in his locis, ubi quaestio dura et obscura aperiri vel solvi non potuit. 
being the most frequently used correction sign in this codex. Despite its use in St. Gallen 904, it should be considered a Continental Carolingian technical sign. ${ }^{74}$

e-shaped sign: a siglum in the form of the minuscule letter e appears over hundred times in Dresden A 145b, being the most frequently used sign in this manuscript (59\% of the pages). Its function remains unclear. A rubricated minuscule e occurs three times in St. Gallen 48.

asteriscus: the asteriscus would have been one of the technical signs most familiar to early medieval scholars. It is described in all the major sign treatises from the period, ${ }^{75}$ because it was used by Jerome to mark differences between the Greek and Hebrew text of the Psalter. ${ }^{76}$ Indeed, asterisci formed a part of the Gallican Psalter, a version of the Psalms that was used in the liturgy both in Ireland and in the Carolingian empire and thus would be a double familiar sight. ${ }^{77}$ Yet, it is unclear how to explain their presence in the two manuscripts examined here, which are not Psalters and where they do not seem to serve an obvious purpose. In St. Gallen 48, asterisci were used to mark Lc 22, 4344 in p. 300. In Bern 363, they appear twice, on ff. $145 \mathrm{v}$ and $151 \mathrm{v}$ to mark passages from the rhetorician Fortunatianus.

oculus: three manuscripts from the set contain an unusual technical signs in the form of a dotted circle, which I call oculus. This sign appears three times in St. Gallen 48 (pp. 192, 193, and 364), twice in Dresden A 145b (ff. 88r and 93v), and twice on f. 29v of Bern 363. Its function is entirely unclear, but it is known also from other Irish manuscripts. ${ }^{78}$

\section{Irish versus Carolingian use of technical signs}

\footnotetext{
74 Most notably, it was the preferred correction sign of Lupus of Ferrières; see C.H. BEESON, Lupus of Ferrières as Scribe and Text Critic: A Study of His Autograph Copy of Cicero's De Oratore (Cambridge, MA, 1930), p. 27. It seems to have been popular in Reims and Tours; see STEINOVÁ, "Notam Superponere Studui”, pp. 208-209, footnotes 771-772.

${ }^{75}$ See for example Isidore, Etym. 1.21.2: Asteriscus adponitur in his quae omissa sunt, ut inlucescant per eam notam, quae deesse videntur. The Anecdoton Parisinum, a sign treatise preserved in an eighth-century manuscript from Monte Cassino, a different tradition about the asteriscus is recorded: Asteriscum Aristofanes apponebat illis locis quibus sensus deesset, Aristarchus autem ad eos qui in hoc puta (sic) loco positi erant, cum aliis scilicet non recte ponerentur; "Notae XXI quae versibvs apponi consvervnt", in Grammatici Latini, ed. H. KEIL, 7 vols. (Hildesheim, 1961), VII, p. 534.

${ }^{76}$ Jerome's use was based on the older convention used by Origen for his Hexapla. Origen understood that the text of the Septuagint differed from the text of the Greek versions of the Old Testament that were independently translated from Hebrew. In his text, he marked passages found only in the Septuagint (representing Greek) but not in the other version (representing Hebrew) with an obelus $(\div)$ and passages present in the Hebrew versions but not in the Septuagint with an asteriscus. The same pair of critical signs was carried over by Jerome into his Gallican Psalter, the Latin version of the Psalms translated from Origen's Hexapla; see F. SCHIRONI, “The Ambiguity of Signs: Critical $\sum \eta \mu \varepsilon \iota \alpha$ from Zenodotus to Origen”, in Homer and the Bible in the Eyes of Ancient Interpreters, ed. M. NIEHOFF (Leiden, 2012), pp. 87-112.

77 They feature already in the oldest surviving manuscript of the Gallican Psalter, the Cathach of St. Columba (6 ${ }^{\text {th }} / 7^{\text {th }}$ century, Ireland); see M. MCNAMARA, "Psalter Text and Psalter Study in the Early Irish Church (600-1200 CE)", in The Psalms in the Early Irish Church (Sheffield, 2000), pp. 28-39. For the Origenian critical signs in early medieval Continental manuscripts, see B. FISCHER, "Die Texte", in Der Stuttgarter Bilderpsalter: Bibl. fol. 23, Württembergische Landesbibliothek, Stuttgart, ed. B. BISCHOFF and F. MÜTHERICH (Stuttgart, 1968), II, 223-288.

${ }^{78}$ Most notably, it appears in the Cathach of St. Columba mentioned in the previous footnote; see CLA II 266.
} 
After this detailed overview of the most significant technical signs occurring in the thirteen manuscripts selected for this study, several general observations can be made. First, signs are a common occurrence in all of the manuscripts examined here. The manuscripts contain between three to sixteen sign types (the average being six or seven). The two manuscripts with the largest number of sign types used are St. Gallen 904 and Bern 363, which both contain around fifteen or sixteen different sign types. Interestingly, the number of sign types varies significantly between manuscript groups. In manuscripts from the Sedulius group, annotators used on average nine to ten sign types, but in the Reichenau group it is only five, excluding the very richly annotated St. Gallen 904. The other manuscripts contain on average only three sign types.

Second, while some signs appear only or significantly more frequently in certain groups, five sign types occur regularly in the entire set, following a single broader pattern. These are: a) the lege

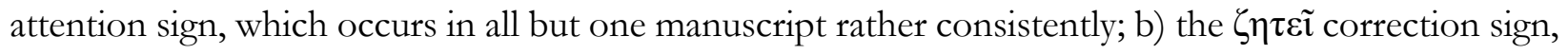
which also appears consistently in the manuscripts from the set, but in small quantities; c) the crosses, which seem to have been employed regularly in different functions; d) the Insular quotation signs (and diple quotation signs in Graeco-Latin codices), which are used rather systematically to mark cited material; and e) the trigon signs, which likewise appears in the majority of manuscripts in small numbers. ${ }^{79}$ These five signs can be considered characteristic of the Irish annotation practices and constitute the 'Irish standard', although it needs to be emphasized that it is by no means a rigid standard and I do not wish to claim that all manuscripts annotated by Irish scribes must contain these five signs. Rather, if these signs are encountered in a manuscript margin, they should be considered as clues for the presence of an Irish annotator. The more of these signs with their characteristic patterns of use are present, the more certain we can be that the annotator was trained in an Irish manner. This conclusion is possible because the Irish mode of annotation is distinct from the Carolingian one. The 'Carolingian standard' will not be described here in detail, since that was already done elsewhere, but allow me to outline the basic differences between the Irish and Carolingian use of technical signs. ${ }^{80}$ The understanding of these differences is both useful for the identification of Irish scribes working on the Continent and for tracing Irish influences on Carolingian annotators and vice versa.

As in the Irish manuscripts, technical signs in Carolingian books fit into several major functional categories that can be used as a basis for comparison. They draw attention to a passage of interest (attention signs), mark lines in need of a correction or checking against a better exemplar (correction and query signs), highlight quoted material (quotation signs), indicate the presence of omissions and direct one to fill-ins in the margin (omission signs), and have several additional functions. What distinguishes the Irish from the Carolingian modes of annotation are the graphic

\footnotetext{
${ }^{79}$ Three other patterns of marginalia use can also be associated with the Irish manner of annotation: the use of Roman numerals to itemise longer passages of text (in nine of the manuscripts examined here, see Appendix I); the use of h-d convention of omission signs (in three manuscripts, see Appendix I); and the use of two graphic variants of the lege and quaestio sigla, one with a crossed shaft, the other without. It is possible that the crossing has a subtle meaning, for example indicating that a task they refer to was completed. For the h- and d-shaped omission signs as an Insular phenomenon, see LOwE, "The Oldest Omission Signs", p. 77. Moreover, the two Priscian manuscripts in the set (Karlsruhe 132 and St. Gallen 904) feature a special type of locative signes de renvoi that may represent an annotation feature particular to the Irish manuscripts of Priscian; see P.-Y. LAMBERT, "Les signes de renvois dans le Priscien de Saint-Gall", Études Celtiques 24 (1987), pp. 217-238.

${ }^{80}$ See STEINOVÁ, “Notam Superponere Studui”, pp. 221-250.
} 
forms employed for the signs representing these functional categories, which can be, in some cases, associated exclusively with the former or the latter.

Most notably, nota monograms mentioned in the introduction of this paper were used as the preferred form of the attention sign in Carolingian manuscripts. In fact, they rank among the most common technical signs in codices from the period. As we have seen, or rather haven't seen, they are absent from Irish manuscripts and this absence is a notable indicator of an Irish annotator. By contrast, lege sigla, which are omnipresent in the manuscripts examined above, are absent from Carolingian annotations. Quotations in Carolingian manuscripts are usually marked by means of an S-shaped flourish, which developed from the diple. ${ }^{81}$ Several other less frequently used quotation signs, such as the Y-shaped yfen and the quotation sign in the form of $\div$, also appear in early medieval Continental manuscripts. ${ }^{82}$ These types of quotation signs do not feature in the set examined here. On the contrary, quotations in these manuscripts are consistently marked by the characteristic Insular type of the quotation sign (or, in the Greek and Graeco-Latin codices, the diple).

Other technical signs cannot be associated with Irish or Carolingian annotation practices on the basis of their exclusive (or near exclusive) occurrence in one or the other. Rather annotators can be shown to use several graphic forms of a sign representing a certain function in a single manuscript context, yet to have a marked preference for a particular graphic form. Thus, the Irish manuscripts studied in this article contain three different types of corrections signs: the $\zeta \eta \tau \varepsilon \tilde{i}$, which appears across all manuscript groups, require, which features only in the Sedulius group, and the cryphia, which occurs only in St. Gallen 904. In this case, the $\zeta \eta \tau \varepsilon \tilde{i}$ should be considered the preferred form as it appears in most manuscripts. ${ }^{83}$

In Carolingian manuscripts, we also see several different types of correction signs, including require, cryphia, and $\zeta \eta \tau \varepsilon \tilde{i}$. However, require is used much more frequently and with greater consistency than the other two sign types and thus it should be considered the standard Carolingian form of a correction sign. ${ }^{84}$ Importantly, when Z $\eta \tau \varepsilon \tilde{\imath}$ appears in a Carolingian manuscript, it has often the form of an Irish minuscule $z$, and not a Carolingian one, while the require signs employed in the Sedulius group resemble the Carolingian $r$ and not the Irish one. These letter shapes may suggests the direction of the transfer of practices, in the case of the $\zeta \eta \tau \varepsilon \tilde{\imath}$ from Ireland to the Continent, and in the case of require from Continental to Irish scribes. ${ }^{85}$

Finally, some signs crop up too rarely in manuscripts, or they do not display a characteristic pattern to be used as evidence for either an Irish or a Carolingian presence in the margin on their own. Yet, in combination with other signs in the manuscript, they may add weight to an argument in one direction or the other. Two of the minor signs, the oculus and $\mathcal{Y}$, are examples of technical signs which

\footnotetext{
${ }^{81}$ For the relationship between the diple and the S-shaped flourish, see LINDSAY, Palaeographia Latina, p. 19.

82 They are mostly found in pre-800 manuscripts. See for example CLA IV 497, V 542, and VI 718.

${ }^{83}$ It also appears as a preferred correction sign in many other manuscripts copied in Insular minuscule, among them the Book of Armagh, Dublin, Trinity College, MS 52 ( $9^{\text {th }}$ century, in., Ireland), the Douce Apocalypse, Oxford, Bodleian Library, MS Douce 140 ( $7^{\text {th }} / 8^{\text {th }}$ century, Insular centre, probably England), Kassel, Universitätsbibliothek, Theol. Fol. 22 ( $8^{\text {th }}$ c., 2/2, Ireland; CLA VIII 1135), and the Bobbio grammatical codex Vienna, Österreichische Nationalbibliothek, MS 16 ( $8^{\text {th }}$ century, Bobbio; CLA III 391).

${ }^{84}$ On the use of require correction signs in Carolingian manuscripts, see STEINOVÁ, "Notam Superponere Studu”, p. 229.

85 On the possibility to trace the provenance of a manuscript based on the correction signs, see also LINDSAY, Palaeographia Latina, p. 13.
} 
seem characteristic for Irish annotation practices and largely unknown to Carolingian annotators. The practices of marking interesting Greek words with a $\Gamma$ sign and of using an o-shaped sigla also seem to be typically Irish. On the other hand, Irish manuscripts are essentially devoid of technical signs derived from Isidore's sign treatise in Etymologiae 1.21, which were adopted by Carolingian annotators in the course of the ninth century. ${ }^{86}$ These include the cryphia (Etym. 1.21.10; $\bullet$ ), frontis (Etym. 1.21.23; $\$)$, and the two anchorae (Etym. 1.21.24-25; $\uparrow \mathrm{d}$ ), which are attested in particular in Frankish Carolingian manuscripts. ${ }^{87}$

The most noteworthy differences between the Irish and Carolingian annotation can be summed up in this table:

\begin{tabular}{|c|c|c|c|}
\hline & Irish $\mathrm{p}$ & ractice & Carolingian practice \\
\hline attention sign & $L$ & t & N $\mathbb{N}$ \\
\hline quotation sign & & "y & 555 \\
\hline correction sign & & h. & $B_{x} r$ \\
\hline other signs & $\Leftrightarrow x$ & - $r$ & $\uplus \$ T d$ \\
\hline
\end{tabular}

While Irish and Carolingian modes of annotation differ in many significant respects, there are also several technical signs that they share and where we cannot see any specific differences that point at an Irish or a Carolingian annotator. Two of the five signs identified earlier as widely used by Irish annotators, the cross and the trigon, are also commonly found in Carolingian manuscripts. The chresimon, too, cannot be taken for a specifically Irish element, even though we have evidence that it was used on the Isles as an attention sign from very early one. ${ }^{88} \mathrm{It}$ is also described by Isidore of Seville (Etym. 1.21.22) and used in Carolingian manuscripts, where it appears next to the other Isidorian signs. ${ }^{89}$ The use of chresimon in the Irish manuscripts and in the Carolingian ones thus seems to stem from different traditions, the Irish one having to do with ancient Greek praxis and the Carolingian one shaped by Isidore's sign treatise. ${ }^{90}$ However, it is not always possible to distinguish a characteristic

86 See STEINOVÁ, “Notam Superponere Studui”, pp. 208-213.

${ }^{87}$ We have, nevertheless, seen that the cryphia was also used in St. Gallen 904, which is the only Irish manuscript that I know of that contains this Isidorian sign.

${ }^{88}$ One of the oldest medieval witness of the chresimon is the Moore Bede (Cambridge, University Library, Kk $\mathbf{5}$ 16, $8^{\text {th }}$ century, 1/2, Northumbria). See, for example, f. 7v, at: http://cudl.lib.cam.ac.uk/view/MS-KK-00005-00016/1.

89 The chresimon seems to have started to appear in Carolingian manuscripts at the same time as other technical signs adopted from the Etymologiae. This could suggests that it was a part of the same parcel of innovative practices that have to do with the study of Isidore's encyclopedia and not an appropriation of a Insular practice. This is also indicated by a peculiar pattern of annotation found in some of the Carolingian manuscripts, which involves the chresimon as a preferred attention sign (rather than the nota monogram) and the frontis as a preferred correction sign (rather than require). These include Bern, Burgerbibliothek, E 219 ( $9^{\text {th }}$ century, 1/2, France), Munich, Bayerische Staatsbibliothek, Clm 6375 ( $9^{\text {th }}$ century, 2/3, northern Italy), Paris, Bibliothèque Nationale de France, Lat. 10292 ( $9^{\text {th }}$ century, 3/4, eastern France), and Paris, Bibliothèque Nationale de France, Lat. 8305 ( $9^{\text {th }}$ century, 4/4, northern France). See STEINOVÁ, "Notam Superponere Studui", p. 213.

${ }^{90}$ It seems that several elements of ancient Greek annotation practices influenced the oldest Insular scribal practices. For example, the characteristic Insular abbreviation symbol for est $(\div)$ is in fact the ancient Greek abbreviation symbol for घĩval; see T.W. ALLEN, "Abbreviations in Greek Manuscripts”, in Abbreviations in Greek: Inscriptions, Papyri, Manuscripts, and 
pattern of use from a shared graphic form. Thus, we are not helped in our search for an identification of either an Irish or a Carolingian annotator. The presence of chresima in the manuscripts from the Sedulius group may be taken either as evidence for an Irish mode of annotation or a Carolingian influence it is best to see them as evidence for two related practices that reinforced each other. After all, if an Irish scribe working on the Continent learned that his Carolingian colleagues employed the same symbol in the same fashion, it may have encouraged him to use it, since it would be understood in both communities of users. Similarly, the Irish usage of the sign may have been a reason why chresimon seems to have been used on the Continent more widely and for a longer period than other 'Isidorian' signs.

\section{Internal differences between manuscript groups}

So far, I have focused on describing the thirteen manuscripts mentioned here and comparing them with Carolingian manuscripts as a single set. However, as can be noted from Appendices II and III, there are also some notable differences between manuscript groups. These differences require to be touched upon, especially as they reveal that the manuscripts from the Sedulius group form a category sui generis, at least with regards to other manuscript examined here.

The specific character of the annotation of the manuscripts from the Sedulius group can be best demonstrated by the comparison of this group with the manuscripts from the Reichenau group. Both groups contain four manuscripts, both were produced on the Continent and both date from roughly the same period. Nevertheless, manuscripts from the Sedulius group contain five technical signs that are entirely absent from the Reichenau group: the $\Gamma$ sign used to mark interesting Greek words, require correction sign, the c-shaped sign, chresimon attention sign, and quaestio sign. These signs appear in these manuscripts frequently and consistently, being the signs most commonly encountered in the Sedulius group, and seem to be used in the same capacity across all four manuscripts from the group. On the contrary, the o-shaped siglum appears in the manuscripts from the Reichenau group, but not a single time in the Sedulius group. Again, the o-shaped sign is used consistently in the Reichenau manuscripts and after the lege sign, it is the most prominent sign employed in these codices.

If we extend the comparison to the other manuscripts, it becomes even clearer that the signs that seem to characterize the manuscripts from the Sedulius group and from the Reichenau group are particular to these two communities. With the exception of St. Gallen 904, they do not appear at all in the other Irish manuscripts examined here. St. Gallen 904 holds a special place among the manuscript examined here, as it contains both signs typical for both groups. Yet, in St. Gallen 904, they do not seem to be used in the same fashion as in the manuscripts from the Sedulius or the Reichenau group and should not be considered to indicate a close relationship to either of the groups. ${ }^{91}$

\footnotetext{
Early Printed Books, ed. A.N. OIKONOMIDES (Chicago, 1974), pp. 146 and 179. For the codicological and paleographical aspects of the oldest Irish manuscripts, see also J. BROWN, "The Oldest Irish Manuscripts and Their Late Antique Background", in Irland und Europa. Die Kirche im Frühmittelalter, ed. P. Ní CHATHÁIN and M. RICHTER (Stuttgart, 1984), pp. 311-327; reprinted in J. Brown, A Palaeographer's View (London, 1993), pp. 221-241 and 287-289.

${ }^{91}$ Traube associated this manuscript with the Sedulius group on account of a poem mourning the death of bishop Gunther of Cologne, the patron of Sedulius, whose name appears among the marginalia in Bern 363, and also other features; see L. TRAuBE, O Roma nobilis: philologische Untersuchungen aus dem Mittelalter (Munich, 1891), p. 51. However, Bischoff was also of the opinion that the paleographic similarities between the manuscripts from the Sedulius circle and St. Gallen 904 do not indicate a connection between the two; see BISCHOFF, "Irische Schreiber im Karolingerreich", pp. 51-52.
} 
The manuscript, which features fifteen different sign types and is thus probably the most richly annotated early medieval Irish manuscript, rather reflects the immense diversity and richness that the Irish annotation practices could attain when their full potential was exploited. The similarities and differences between the manuscripts from the Sedulius and the Reichenau groups and St. Gallen 904 could be interpreted as suggesting that the members of these communities drew on a particular repertoire of sign forms and meanings that was known in the Irish milieu, selecting signs with functions relevant to their scholarly activities and employing signs reserved for particular operations with greater consistency. The remaining manuscripts examined in this study echo a more mundane aspect of this Irish repertoire, featuring overall only the three most common sign types. ${ }^{92}$

While, then, the members of the Sedulius circle and the annotators working on the Reichenau manuscripts adhered to the same general 'Irish standard' -employing the lege attention sign, Insular quotation sign, and $\zeta \eta \tau \varepsilon \tilde{\imath}$ query sign for standard tasks-, they also engaged in practices of annotation that were particular to their communities and that distinguished them from others. It remains to be seen whether other Irish manuscripts confirm this picture, and also whether, now that certain technical signs can be shown to have been specific for the Sedulius circle, new manuscripts related to this group can be uncovered.

\section{Conclusion}

Early medieval Irish readers were vigorous users of technical signs, just as Carolingian readers. They employed a number of characteristic technical signs that allow us to distinguish them from Carolingian readers and writers from the same period. The underlying feature of the Irish mode of annotation is

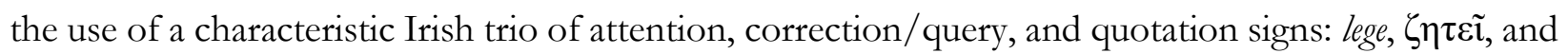
the Insular quotation sign (in contrast to nota, require, and S-shaped flourish used in Carolingian codices). ${ }^{93}$ Apart from these three signs, crosses and triga also rank among the most common Irish technical signs; however, they also occur in Carolingian manuscripts and thus cannot be considered specific to the Irish mode of annotation.

The manuscripts presented here also reflect differences between sign users from various Irish communities, particularly in the manuscripts from the circle of Sedulius. Their annotators used five signs not commonly found in other Irish manuscripts: require, which reflects Carolingian annotation practices; chresimon, which may also be a sign of Carolingian influence on the group; the $\Gamma$ symbol employed to mark interesting Greek words; the q-shaped quaestio sign, and the c-shaped sign the purpose of which is unclear. The three latter signs are Irish in character and may have been selected from a repertoire of signs already known in the Irish milieu, but not employed commonly. The presence of these technical signs may provide grounds for linking manuscripts with the Sedulius circle, especially if multiple signs characteristic for the Sedulius circle feature in them. Interestingly enough,

\footnotetext{
92 It can be, similarly, noted that Pal. Lat. 68, the only manuscript included in this comparison that was produced in England, displays the least affinity with other manuscripts examined here, containing no lege and $\zeta \eta \tau \varepsilon \tilde{\imath}$ signs, but a large number of crosses and $\mathcal{C}$-shaped signs.

${ }^{93}$ It may be pointed out that precisely these three signs, and no other, are to be found in the Book of Armagh, Dublin, Trinity College, MS 52 (9 $9^{\text {th }}$ century, in., Ireland). The manuscript is digitized at: http://digitalcollections.tcd.ie/home/\#folder id=26\&pidtopage=MS52 01\&entry point=1.
} 
signs characteristic for the Sedulius group are absent from the Psalter of Sedulius, which suggests that this manuscript is not affiliated with the manuscripts from this group.

The findings of this study should, of course, be expanded by the examination of additional manuscripts to refine it and fill in the gaps. But the conclusions presented here, based on my small sample, already provide us with important insights into the Irish annotation practices. To conclude, allow me to demonstrate how even the basic understanding of Irish technical signs can help us to make observations about the origin, provenance and context of use of early medieval manuscripts.

First, technical signs can point out Irish manuscript-users on the Continent, even when we have no other traces that would point in that direction, no names or characteristic hands. For example, Munich, Bayerische Staatsbibliothek, Clm 14425, a copy of Jerome's commentary on Jeremiah, which was produced around the turn of the ninth century at the monastery of St. Emmeram in Regensburg in Caroline minuscule, contains a rich layer of characteristic Irish technical signs. ${ }^{94}$ In Bern, Burgerbibliothek, MS 224, an early ninth-century copy of the Etymologiae produced in Caroline minuscule in a Frankish center, a hand not found elsewhere in the manuscript added lege signs, a chresimon, and Roman numerals in the margins of the second book of Isidore's encyclopedia on ff. 15v, $16 \mathrm{v}$, and 20r. The combination of these features places this annotator in the Irish milieu on the Continent. $^{95}$

Second, technical signs can be instrumental in tracing the activity of known Irish scholars and their circles, particularly when their workshops used Caroline minuscule. A case in point is Laon, Bibliothèque municipale, MS 468, the handbook of Martin of Laon. Although Martin was an Irishman, he adopted Caroline minuscule and this script was also used by his students in Laon. Yet, in the margin of Laon 468 we find several characteristic Irish sign types, such as the oculus, which is used abundantly throughout the glossaries of Virgil and Sedulius on ff. 18r-61r. ${ }^{96}$ John the Scot can be shown to have employed the $\zeta \eta \tau \varepsilon \tilde{\imath}$ sign and the chresimon. ${ }^{97}$

${ }^{94}$ This layer consists of numerous lege signs (covering $40 \%$ of the pages in this manuscript), Insular quotation signs (26\% of pages), crosses (14\% of pages) peculiar $\mathrm{C}$ and $\mathrm{J}$ signs, chresima and zig-zags. Two other layers of technical signs feature in this manuscript. A layer that predates the activity of the Irish annotator was entered by the scribe consists of yfen and another type of quotation signs. A layer that is younger, as we can tell from the way they are positioned in the margin, was added by a Carolingian annotator who marked certain passages from Jerome's commentary with $\mathrm{n}$ - and $\mathrm{f}$-shaped excerption signs, found in other Regensburg manuscripts from the period. He also entered a single require sign on f. $93 \mathrm{v}$. The manuscript is digitized at: http://daten.digitale-sammlungen.de/bsb00046482/image 1. Bernhard Bischoff identifies the author of the Irish layer of signs as a 'Celtic scribe' and suggests that he was in fact not an Irishman but a Welshman; B. BISCHOFF, Die südostdentschen Schreibschulen und Bibliotheken in der Karolingerzeit, 2 vols. (Wiesbaden: 1960), I, pp. 181 and 191.

${ }^{95}$ The same hand added two interlineal corrections on f. 20r. In the ninth century the manuscript was kept in Strasbourg, a provenance shared by other manuscripts from the Sedulius group. Bernhard Bischoff suggested, therefore, that the annotator may have been a member of the circle of Sedulius; BISCHOFF, "Irische Schreiber im Karolingerreich", p. 52. The pattern of sign use in this manuscript is consistent with the annotations in the Sedulius group, but does not suffice on its own to prove that the annotator was a member of this circle.

${ }^{96}$ The same section of the manuscript also contains many asterisci, which, as we have seen, were used in Irish annotation practices.

${ }_{97}$ See, for example, one of the manuscripts with autograph corrections and notices by John, Laon, Bibliothèque municipale 81 (third quarter of the ninth century; circle of John the Scot), in which $\zeta \eta \tau \varepsilon \tilde{\imath}$ can be found on f. 18v, at: http://manuscrit.ville-laon.fr/ app/visualisation.php?.cote $=\mathrm{Ms} 81 \& v u e=40 \# 40 . \quad$ Chresima are found in another manuscript containing John's autograph, Bamberg, Staatsbibliothek, MS Ph. 2/1 (third quarter of the ninth century; circle of John the Scot), at: http://bsbsbb.bsb.lrzmuenchen.de $/ \sim \mathrm{db} / 0000 /$ sbb00000177 $/$ images $/$ index.html?id $=00000177 \&$ nativeno $=7 \mathrm{r}$. The hand of John the Scot and 
Finally, Irish technical signs can help us to uncover lost Irish prototypes of manuscripts copied in non-Irish scripts. A fascinating case is the eleventh-century manuscript of the Collectanea of Sedulius Scottus from Metz, Bamberg, Staatsbibliothek, Msc. Bibl. 127, in which the scribe diligently copied a number of chresima and $\zeta \eta \tau \varepsilon \tilde{\imath}$ signs from the prototype, clearly without a good understanding of what they mean because he painted them rather than traced them with his pen. The shape of these signs reveals that the prototype was, in all likelihood, a ninth-century manuscript annotated by an Irish hand, perhaps an Irish book itself. Brussels, Koninklijke Bibliotheek, MS 5169 ( $9^{\text {th }}$ century, 2/2, France), a copy of Prosper's Chronicon produced in Caroline minuscule contains a rich layer of uncharacteristic signs entered by the main hand. They include many asterisci, oculi, $\supset$ signs, and serpents that mark notices about infamous heretics. Possibly, this is a copy of an earlier manuscript annotated by an Irish scholar.

As we can see, technical signs can be studied without running into the danger of their overinterpretation. They are of great value to the scholars of early medieval manuscripts and deserve our further interest and systematic study. A further examination of Irish manuscripts will certainly reveal additional details about the Irish annotation practices, which will refine our understanding of early medieval intellectual culture.

his amanuensis was described in great detail in É. JEAUNEAU and P.E. DUTTON, The Autograph of Eriugena (Turnhout, 1996). 


\section{Appendix I: Description of technical signs in the manuscripts used in this study}

\section{A. Manuscripts from the Sedulius group}

\section{St. Gallen, Stiftsbibliothek, MS 48}

Greek Gospels with Latin interlineal gloss ('Codex Delta')

$9^{\text {th }}$ century, $2 / 4$ or mid- $9^{\text {th }}$ century, Continent, possibly northern Italy

http://www.e-codices.unifr.ch/en/searchresult/list/one/csg/0048

395 pages, Greek majuscule for the main text, Irish minuscule for the gloss

BK 5534; Lindsay, pp. 47-50; Kenney, p. 558; Bischoff, 'Irische Schreiber', pp. 51-52

Most important signs: require ( $\mathrm{r}, \mathrm{x} 99)$, lege $(1, \mathrm{x} 90)$, the $\mathrm{c}-\mathrm{sh} a p e d$ sign $(\mathrm{x} 85), \Gamma$ (graecum, $\mathrm{x} 49)$, the $\mathrm{T}$ shaped sign (to mark the beginning of a new section, x34), quaestio (q, x33), diple (>, x32), chresimon

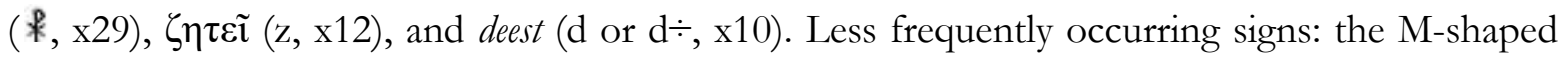
sign (x6), cross (x4), the e-shaped sign (x3), oculus ( $\odot, x 3)$, and asteriscus ( $\%, \mathrm{x} 1)$.

The signs were added by the main glossing hand during the process of production. This is indicated by the Eusebian canons added to the Gospels in the margins, which in many cases have been entered on top of the already present technical signs. In pp. 187 and 383, for example, a require sign appears under the Eusebian canons, and in pp. 244 and 292, the $\Gamma$ sign was similarly overlaid with a Eusebian canon. In p. 347, the lege sign and the chresimon were coloured with the same scheme as chapter headings and most of the diple signs.

The signs are distributed unevenly. T's do not appear after p. 306, and can mostly be found between pp. 100 and 200, lege is rare after p. 300, and $\Gamma$ appears only a few times after p. 200. By contrast, three signs appear more frequently in the second half of the manuscript: c's occur fourteen times in the first 200 pages, but forty-six times in the last 100 pages, chresimon appears more frequently only after p. 200, and quaestio after p. 300.

As in other manuscripts from the Sedulius group, technical signs in St. Gallen 48 are frequently combined. The most common combinations include c's with quaestio (x10), c's with lege (x8) and c's with chresimon (x7). Chresimon does not appear in combination with any other sign but c, while $\mathrm{c}$ is most commonly combined with another sign (x30). Several of the signs are also combined with textual notes: quaestio five times, ${ }^{98}$ c three times, ${ }^{99}$ and lege once. ${ }^{100}$ In p. 7, Roman numerals are used to divide the text into items. Following names of contemporary personages appear in the margins: Agano (x7), Dub(thach?) (x3), Gunther (x2), Gottschalk (x2), Lupus (x1), Rem(igius?) (x1), Sedulius (x1), and Adal(berga?) (x1). Of the authors: Priscian (x10), Martianus Capella (x10), Donatus (x4), and Boethius (x1). Most of the other marginal notes in this manuscript explain Greek words in the main text, just like in Basel A VII 3, or identify an important episode in the Gospels (e.g. in p. 188: titulus sanctae crucis).

\footnotetext{
98 On p. 79 with $\mathrm{A} \Delta \mathrm{A} \Lambda$ (possibly a reference to queen Adalberga, who is also referenced in Bern 363), on p. 104 with AГA (for Agano, who is also referenced in Bern 363), on p. 327 with baptizmum Christi, in p. 376 with in Roma, and on p. 388 with $d u b$ (the same reference is frequently found in Bern 363, possibly for Dubthach).

${ }^{99}$ On p. 351 with iou, in p. 362 with ad, and on p. 377 with Sedul (Sedulius, who is also referenced in Bern 363).

100 On p. 105 with pris (Priscian, who is also referenced in other manuscripts from the Sedulius group).
} 
The hand of the Bern master copied and annotated texts in pp. 1, 2 and 395. The signs he used include: chresimon ( $\mathbb{*}, \mathrm{x} 1)$, and $\zeta \eta \tau \varepsilon \tilde{\mathrm{i}}(\mathrm{z}, \mathrm{x} 1)$.

\section{Basel, Universitätsbibliothek, A VII 3}

Greek Psalter with interlineal Latin gloss

$9^{\text {th }}$ century, $3 / 4$, Continent

http://www.e-codices.unifr.ch/en/searchresult/list/one/ubb/A-VII-0003

99 ff., Greek majuscule for the main text, Irish minuscule for the gloss

BK 255; Lindsay, pp. 47-50; Kenney, pp. 557-58; Bischoff, 'Irische Schreiber', pp. 51-52

Most important signs: $\Gamma$ (graecum, on $\mathrm{f} .52 \mathrm{r}$ as g, $\mathrm{x} 103$ ), lege (1, $\mathrm{x} 84$, on $\mathrm{f} .63 \mathrm{v}$ written in full as lege titulos canticorum), require ( $\mathrm{r}, \mathrm{x} 73$ ), the c-shaped sign (x34), chresimon ( $\mathbb{*}, \mathrm{x} 11)$, deest (d or $\mathrm{d} \div, \mathrm{x} 7)$, and $\zeta \eta \tau \varepsilon \tilde{\mathbf{i}}(\mathrm{z}, \mathrm{x} 3)$. Less frequently occurring signs: fabula (f, x3), the s-shaped sign (semper?, $\mathrm{x} 2)$, quaestio (q, x2), and uersus (v, x1).

For the most part, the signs were entered by the main glossing hand, but some of the lege signs in the first thirty folia of the manuscript were made by a different hand writing in light ink. Of the signs listed, $\Gamma$ deserves special attention, not only because it appears in this manuscript more often than in any other codex, but also because in twenty-one instances, it is accompanied by a marginal note explaining a Greek word in the main text:

\begin{tabular}{|c|c|}
\hline $7 \mathrm{r}, 19$ & HXOrC (Ps 9, 7) $\mid \Gamma$ echo \\
\hline $8 \mathrm{r}, 1$ & Cr $\Lambda \Lambda$ AMBANONTAI (Ps 9, 23) | $\Gamma$ silla(?) \\
\hline $8 \mathrm{r}, 10$ & АПОКРҮФОІС (Ps 9, 29) | Г apogripha \\
\hline $33 r, 4$ & CrNAEEI $(\mathrm{Ps} 38,7) \mid \Gamma$ synaxis congregatio \\
\hline $52 \mathrm{r}, 11$ & $\triangle$ IECTEI $\Lambda$ AN $($ Ps 65,14$) \mid g$ diastole \\
\hline $53 \mathrm{v}, 16$ & ANATOLAS (Ps 67,34$) \mid \Gamma$ anatolius uel prae(?) orientalis \\
\hline $54 \mathrm{r}, 15$ & EENOC $($ Ps 68,9$) \mid \Gamma$ inde EENIA hospitia \\
\hline $57 \mathrm{v}, 16$ & П $\Lambda$ OYTOY (Ps 72, 12) | Г plutoN \\
\hline $60 \mathrm{r}, 1$ & 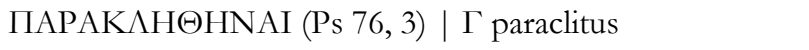 \\
\hline $60 \mathrm{r}, 8$ & АПОКОЧЕI (Ps 76, 9) | Г apogope (apagope a.c.) \\
\hline $66 \mathrm{v}, 17$ & KPATOC $($ Ps 85,16$) \mid \Gamma$ pantocrator \\
\hline $73 r, 12$ & АПЕКА $\Lambda \Psi E N(P s$ 97, 2) | $\Gamma$ apekalipsis (second hand) \\
\hline 76r, 16 & ПНГАСЕN (Ps 103, 10) | Г pegasus (pegacus a.c.) \\
\hline 79r, 8 & NEKPSN (Ps 105, 28) | $\Gamma$ nekromancia \\
\hline 79r, 14 & $\triangle$ IECTEI $\Lambda$ EN (Ps 105, 33) $\mid \Gamma$ diastole \\
\hline $83 r, 6-7$ & OIKONOMECEI (Ps 111, 5) $\mid \Gamma$ equonomus \\
\hline $85 \mathrm{v}, 21$ & 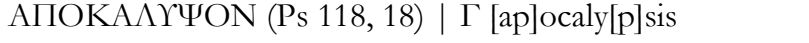 \\
\hline 86r, 12 & AKH $\Delta \mathrm{IAC}(\operatorname{Ps} 118,28) \mid \Gamma$ acidia \\
\hline $88 \mathrm{v}, 6-7$ & АПОСТАТОYNTAC (Ps 118, 118) | Г apostata \\
\hline $91 \mathrm{r}, 15$ & BA $\Lambda \Lambda$ ONTEC $($ Ps 125,6$) \mid \Gamma$ baiolat \\
\hline $94 \mathrm{v}, 10$ & ГАСТРОC $($ Ps 138,13$) \mid \Gamma$ gastrimargia \\
\hline
\end{tabular}

The signs appear regularly throughout the entire manuscript, with the exception of c's which appear only twice in the first half of the manuscript and chresimon which appears only from $\mathrm{f} .58 \mathrm{v}$ onwards.

The combination of signs and signs with marginal notes is very prominent. Notable are the couplings of $\Gamma$ with other signs: with lege ( $x 53$, so that most lege signs occur next to a $\Gamma$ ), with 
require (x13), and with chresimon (x10, so that with a single exception, chresimon is always coupled with a $\Gamma$ ). Four authorities are mentioned in the margins: Priscian (x8), Martianus (f. 48v), Cassiodorus (f. 81r), and on f. 78r scip perhaps refers to Macrobius's commentary on Somnium Scipionis. In f. 61r, Genesis is cross-referenced (Genesin lege). The manuscript also contains a number of marginal notes, mostly referring to Greek words in the main text (including a very long explanatory gloss on $\mathrm{f} .51 \mathrm{v}$ ). In the margin of $\mathrm{f}$. $23 \mathrm{r}$ is an important note referring presumably to Moengal-Marcellus: hucusque scripsi binc incipit ad Marcellum nunc. Roman numerals dividing the text into items can be found on f. 98v.

The hand of the Bern master copied and annotated texts on ff. $1 \mathrm{v}-3 \mathrm{v}$ and $98 \mathrm{r}-99 \mathrm{v}$. Signs used in these folia include: c-shaped sign (x4), s-shaped sign (semper, x3), Insular quotation sign (., x1), f-

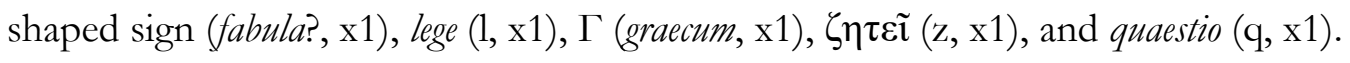

\section{Dresden, Sächsische Landesbibliothek, A 145b}

Greek Pauline epistles with interlineal Latin gloss ('Codex Boernerianus')

$9^{\text {th }}$ century, 2/3, Continent

http://digital.slub-dresden.de/werkansicht/dlf/2966/1/

99 ff., Greek majuscule for the main text, Irish minuscule for the gloss

BK 1040; Lindsay, pp. 47-50; Kenney, p. 559; Bischoff, 'Irische Schreiber', pp. 51-52

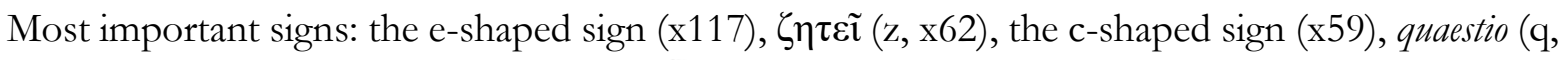
$\mathrm{x} 48)$, lege $(1, \mathrm{x} 37)$, diple $(>, \mathrm{x} 36)$, chresimon ( $(\mathbb{x}, \mathrm{x} 35), \Gamma$ (graecum, $\mathrm{x} 22)$, require $(\mathrm{r}, \mathrm{x} 6)$, and deest $(\mathrm{d} \div, \mathrm{x} 3)$. Less frequently occurring signs: oculus $(\odot, \mathrm{x} 2)$ and cross $(\mathrm{x} 1)$.

The signs were for the most part added by the main hands. This is the only manuscripts from the Sedulius group in which the $\zeta \eta \tau \varepsilon \tilde{i}$ rather than the require was used systematically for correction. The signs occur regularly throughout the entire manuscript.

As in other manuscripts from the Sedulius group, technical signs in Dresden A 145b are frequently combined. Notably, e-shaped sign and c-shaped sign occur together twenty-six times (mostly on ff. 59r-72v). Other combinations include $\mathrm{c}$ and quaestio, $\mathrm{c}$ and lege, and e and lege. Roman numerals are used as division marks on ff. 20r-21r. Omissions are marked with $\mathrm{d}$ and h omission signs. Authorities mentioned in the margins include Martianus Capella (x7) and Priscian (x2, on ff. 55r and 95r). Contemporary personages mentioned include Aga(no) (x3), John (x3), and Dub(thach) (x1). Other marginalia in this codex include several textual notes (lectio ad missam on f. $11 \mathrm{r}$, diab on f. $62 \mathrm{r}, e p(i) s($ copus $)$ on f. $59 \mathrm{v}$, and $e b($ raei $)$ on $\mathrm{f} .77 \mathrm{v})$.

The hand of the Bern master copied and annotated texts on ff. Irv, 99v and 1br-11bv. Signs used by this hand include: Insular quotation sign (., x22), quaestio (q and crossed q, x20), lege (1, x17), the M-shaped sign (mystice?, x16), the s-shaped sign (semper?, $\mathrm{x} 8$ ), the c-shaped sign (x7), chresimon ( $*, \mathrm{x} 5,0.2), \zeta \eta \tau \varepsilon \tilde{\mathrm{i}}(\mathrm{z}, \mathrm{x} 1)$, and $\Gamma$ (graecum?, $\mathrm{x} 1)$.

\section{Bern, Burgerbibliothek, MS 363}

Servius, Commentarii in Vergilium (ff. 2r-142v); various treatises on rhetoric and dialectic (ff. 143r166v); Horace, Carmina (ff. 167r-186v); excerpts from the third book of the Metamorphoses (ff. 
187r-188v); Bede, Historia ecclesiastica gentis Anglorum (ff. 188v-194r); various poems and excerpts (ff. 194r-197v) ('Bern Horace')

$9^{\text {th }}$ century, $3 / 4$, Continent, perhaps St. Gallen? (Bischoff)

facsimiles in Herman Hagen, Codex Bernensis 363 phototypice editus. Codices graeci et latini photographice depicti 2. Leiden: Sijthoff, 1897.

197 ff., Irish minuscule

BK 585; Lindsay, pp. 50-54; Kenney, pp. 559-60; Bischoff, 'Irische Schreiber', pp. 51-52

Most important signs: quaestio (q, x293), Insular quotation sign (., x282), chresimon ( ( , x172), fabula

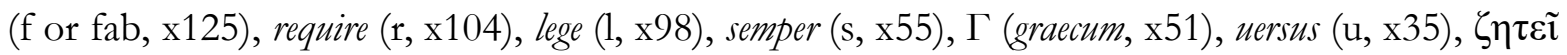
$(\mathrm{z}, \mathrm{x} 32)$, and the $\mathrm{c}$-shaped sign (x27, used often with s). Less frequently occurring signs: cross ( $\mathrm{x} 9$ in Servius), T-shaped sign ( $\mathrm{x} 7$ in dialectical section, Ovid, Bede and poems), deest $(\mathrm{d} \div, \mathrm{x} 4-5)$, asteriscus ( $\circledast, \mathrm{x} 2$ in rhetoric section), trigon $(: ; \mathrm{x} 2$ in dialectical section), and oculus $(\odot, \mathrm{x} 1$ in Servius). Both quaestio and lege appear in a plain form and with their shafts crossed.

The signs and also textual annotations were added at different occasions. This is evident from the fact that some of the marginalia overlay signs entered earlier (e.g. ff. 6r, 33v, and 48r). Also, the younger signs are drawn in darker ink and are mostly larger than the signs in the older layer. Whether there are only two layers is unclear. Some of the signs were perhaps copied from the prototype (e.g. fabula and require in Servius).

In multiple cases, sigla alternate with whole or abbreviated words so that it can be deduced what their meaning is. Thus, the siglum $\mathrm{f}$ can be resolved as fabula, because the same marker occurs as fab in many places and on $\mathrm{f} .36 \mathrm{v}$ it even appears written in full. Other sigla that can be deciphered in a similar fashion are: $\mathrm{q}$ which is on ff. $31 \mathrm{r}, 35 \mathrm{v}$ and $80 \mathrm{r}$ written in full as quaestio; 1 which on ff. $21 \mathrm{r}, 85 \mathrm{r}$ and elsewhere is written in full as lege; c and s which frequently appear together as cor semper, $\mathrm{d} \div$ which is on $\mathrm{f}$. $30 \mathrm{r}$ written as $d e \div$ and on $\mathrm{f}$. $28 \mathrm{r}$ occurs in full as deest, u which appears on ff. $83 \mathrm{r}$ and $138 \mathrm{v}$ as uersus; and finally $\mathrm{z}$ which appears on $\mathrm{f} .129 \mathrm{r}$ accompanied by a marginal note $\operatorname{corr}(i) g[$ ere?] nec[essarium?].

Certain technical signs appear or are used consistently only in some sections of the manuscript. For example, fabula appears only in Servius (covering 44\% of the pages of this section). The Insular quotation sign and the require appear almost exclusively in Servius (the former in $99 \%$, the

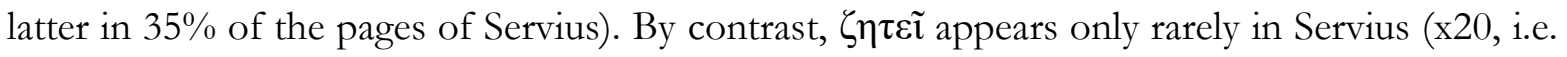
$7 \%$ of pages) and it is the dominant correction sign in Horace and Ovid (x8, i.e. $18 \%$ of pages). Another case is the quaestio sign and the chresimon, which are in Bern 363 commonly attached to the names noted in the margin (Sedulius, Iohannes, Dodo, etc.). However, quaestio feature almost exclusively in Servius (in x266, i.e. 94\% of pages), while chresimon is the preferred form in texts other than Servius: it appears ninety-one times in Servius (32\% of pages) and eighty-one times in the rest of the manuscript (74\% of pages, including $80 \%$ of pages in Horace and Ovid, and $91 \%$ of pages in Bede). The T-shaped sign, the trigon, and the asteriscus appear only in the parts of the manuscript other than Servius. The combination of the c-shaped sign and semper appears only once in Servius (on f. 92r) and even in this case they were added secondary. 
The signs are commonly combined with textual notes: quaestio ten times ${ }^{101}$, chresimon five times ${ }^{102}$, and fabula once. ${ }^{103}$ Roman numerals are used as section markers on ff. 2r, 9r, 58v-59r, 118r, 139r and $139 \mathrm{v}$. Names of various authorities and contemporary personages are mentioned in the margin. Their full list can be found in the introduction of Hagen's facsimiles. ${ }^{104}$

\section{B. Manuscripts from the Reichenau group}

\section{Karlsruhe, Badische Landesbibliothek, Aug. Perg. 132}

Priscian, Institutiones grammaticae

mid- $9^{\text {th }}$ century, northern France

http://digital.blb-karlsruhe.de/blbhs/content/titleinfo/64199

$107 \mathrm{ff}$., Irish minuscule and half-uncial, copied for the most part by the same hand as Karlsruhe Aug. Perg. 195 (Augustine), glossed partially by the same hand that glossed Karlsruhe Aug. Perg. 167 (Bede)

BK 1656; Lindsay, pp. 60-64; Kenney, pp. 675-76; Bischoff, 'Irische Schreiber', pp. 53-55

Most important signs: cross ( $\mathrm{x} 42$, used to mark sections), the o-shaped sign (x27), uersus (u, $\mathrm{x} 27)$, lege $(1, \mathrm{x} 20)$, and two dots (x6). Less frequently occurring signs: trigon $(: \cdot \mathrm{x} 3)$, Insular quotation

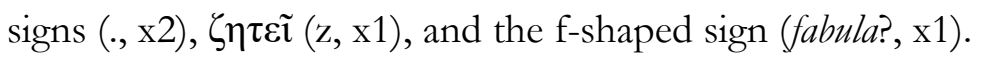

The manuscript also contains special signes de renvoi that connect material in different pages of the codex. These signes de renvoi are in some cases inserted in rubrics and contain little tags ante and post that direct one to the preceding or following pair (e.g. on ff. $56 \mathrm{v}$ and $57 \mathrm{r}$ ). Roman numerals were used as section markers on ff. 20rv, 67v, 70v-71r, and 104v-105v. Omission signs d and h are used consistently.

The crosses and Insular quotation signs are also rubricated. The uersus and lege signs, as well as

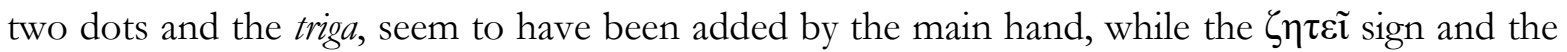
o-shaped signs were inserted by a second hand using lighter ink.

\section{Karlsruhe, Badische Landesbibliothek, Aug. Perg. 167}

Bede, De temporum ratione, De natura rerum (ff. 18r-45v); other computistic works and excerpts before 855, northern France

http://digital.blb-karlsruhe.de/blbhs/Handschriften/content/titleinfo/20736

49 ff., Irish minuscule and half-uncial, glossed partially by the same hand that glossed Karlsruhe Aug. Perg. 132 (Priscian)

BK 1676; Lindsay, pp. 54-57; Kenney, pp. 670-71; Bischoff, 'Irische Schreiber', pp. 53-55

Most important signs: Insular quotation signs (., x34), lege (1, x19), and the o-shaped sign (x8). Less

\footnotetext{
$101 \mathrm{On}$ ff. 38r (de planetis), 45r (contra pictorem), 55v (de ione), 76r (de hesperia), 78r (de regula laudis), 79r (de amore instabili), 107r (de apostolo), $123 \mathrm{r}$ (credo uitam post mortem), 128v (de ramo aureo), and $136 \mathrm{r}$ (epistula).

$102 \mathrm{On} \mathrm{ff.} \mathrm{30v} \mathrm{(facilia} \mathrm{sunt} \mathrm{georgica),} \mathrm{34v} \mathrm{(de} \mathrm{medicina),} \mathrm{95v} \mathrm{(de} \mathrm{insola} \mathrm{creta),} \mathrm{104v} \mathrm{(de} \mathrm{flexu} \mathrm{genumm} \mathrm{ut} \mathrm{scotti} \mathrm{faciunt),} \mathrm{and} \mathrm{191r} \mathrm{(de}$ scottorum fide).

103 On f. 53r (de morte prestantiore).

104 HaGEN, Codex Bernensis 363, pp. xliii-lxviii.
} 
frequently occurring signs: cross $(\mathrm{x} 3)$, and $\zeta \eta \tau \varepsilon \tilde{\mathbf{l}}(\mathrm{z}, \mathrm{x} 2)$. It is unclear whether the five M-shaped symbols that appear in this manuscript should also be considered technical signs.

Apart from the lege signs, technical signs feature only in Bede's works.

\section{Karlsruhe, Badische Landesbibliothek, Aug. Perg. 195}

Augustine, Soliloquia, Liber de praesentia Dei; other smaller texts

c. 850, northern Francia

http://digital.blb-karlsruhe.de/blbhs/Handschriften/content/titleinfo/3298726

$47 \mathrm{ff}$., Irish minuscule and half-uncial, mostly written by the same hand that copied Aug. Perg. 132 (Priscian)

BK 1692; Lindsay, pp. 57-60; Kenney, pp. 669-70; Bischoff, 'Irische Schreiber', pp. 53-55

Most important signs: lege (1, x35), the o-shaped sign (x13), the d-shaped sign (d, x7), and cross (x6). Less frequently occurring signs: trigon $(: \cdot, \mathrm{x} 2)$.

The function of two of the signs used in this manuscript can be guessed from their pattern of use. The crosses appear in six consecutive pages and mark altogether twelve passages, which suggests that they mark liturgical readings. The d-shaped sign occurs in two sets of folia: $10 \mathrm{v}-13 \mathrm{r}$ and $23 \mathrm{r}-29 \mathrm{v}$. In the former, it appears next to the lines in which the words were glossed .i. .d. (perhaps for id est definitio?). Roman numerals were used as section markers on ff. 9v-10v, 12rv, $17 \mathrm{v}$, and $18 \mathrm{rv}$.

The lege and o-shaped signs were made both by the main hand and a second hand using lighter ink. The crosses were all added by a hand of an altogether different annotator. The d-shaped signs were made either by the main hand or by the glossing hand, both of which use similar dark ink.

\section{St. Paul in Lavanttal, Stiftsbibliothek, MS 86a/1}

miscellaneous content both in Latin and Old Irish ('the Reichenauer Schulheft')

early $9^{\text {th }}$ century, Reichenau or St. Gallen

http://hildegard.tristram.de/schulheft/

8 ff., Irish minuscule, connected paleographically with Aug. Perg. 195 (Augustine)

BK 5943; Bischoff, 'Irische Schreiber', pp. 54-55

Given that this manuscript consists of a single quire, there are only very few signs: the o-shaped $\operatorname{sign}(\mathrm{x} 3)$, uersus $(\mathrm{v}, \mathrm{x} 1)$, lege $(1, \mathrm{x} 1)$, and trigon $(: \cdot, \mathrm{x} 1)$.

\section{Other manuscripts examined in this study}

\section{Vatican, Biblioteca Apostolica Vaticana, MS Pal. Lat. 68}

Glossa in Psalmos

$8^{\text {th }}$ century, northern England

http://digi.vatlib.it/view/bav pal lat 68/0008

46 ff., Insular minuscule combining Irish and Anglo-Saxon features

CLA I 78; Lindsay, pp. 67-70; Kenney, p. 637 
Most important signs: Insular quotation signs (x90), cross (x63), the $\mathcal{-}-$-shaped sign (moraliter, 21 , appears as - -cor on f. 38r), and the h-shaped sign (for historialiter or bieronymus, x20).

The crosses appear regularly at the beginning of a new section and thus clearly function as section markers. The $\mathcal{r}$-shaped signs, which should be resolved as moraliter, refer to the four-fold interpretation of the Scripture. Other references to this method of exegesis in the manuscript include marginal cues hist(orialiter) referring to the historical sense, which occur on ff. $2 \mathrm{v}, 18 \mathrm{v}, 29 \mathrm{v}$ and 30r, and a marginal note on $\mathrm{f}$. 25r referring to the allegorical sense (baec omnia iuxta alligoriam conueniunt). Other marginalia include references to Jerome (x10) and Hilary (x1), several interlinear and marginal notes (e.g. on ff. 19r and 20v), and Roman numerals used as section markers on ff. 26rv.

Many of the signs are partially or wholly erased, for example on ff. $18 \mathrm{v}$ and $29 \mathrm{v}$. The $\mathcal{H}$-shaped signs and the h-shaped signs appear consistently in the first twenty folia and the former also return from $\mathrm{f} .37 \mathrm{v}$ onwards, but the middle part of the manuscript contains only the quotation signs and the crosses.

\section{Würzburg, Universitätsbibliothek, Mp.th.f.12}

Pauline epistles with Old-Irish glosses

$8^{\text {th }}$ century, $2 / 2$, Ireland

facsimiles in Ludwig Stern, Epistolae beati Pauli glosatae glosa interlineali: Irisch-Lateinischer codex der Würzburger Universitätsbibliothek. Halle: Niemeyer, 1910.

36 ff., Irish minuscule

CLA IX 1403; Kenney, pp. 635-36

Most important signs: trigon $(: \cdot \mathrm{x} 20)$, and lege $(1, \mathrm{x} 6)$. Less frequently occurring signs: Insular quotation sign (., x3), and cross (x1).

The lege signs, Insular quotation signs and the cross were inserted by the main hand, while the triga were made by the glossator.

\section{Milan, Biblioteca Ambrosiana, C 301 inf.}

Psalm commentary with Old-Irish glosses

$8^{\text {th }} / 9^{\text {th }}$ century, Ireland or Bobbio

facsimiles in Richard I. Best, The Commentary on the Psalms with glosses in Old-Irish preserved in the Ambrosian Library. Dublin: Royal Irish Academy, 1936.

146 ff., Irish minuscule

CLA III 326; Lindsay, pp. 70-74; Kenney, p. 665

Most important signs: lege $(1, \mathrm{x} 58)$, two dots $(\bullet, \mathrm{x} 36)$, and trigon $(\bullet ; \mathrm{x} 21)$. Less frequently occurring

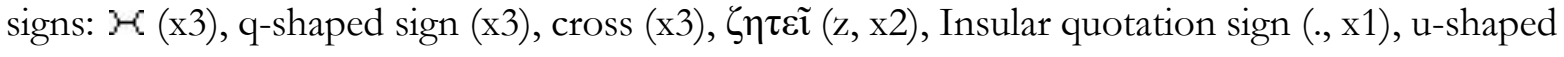
sign $(\mathrm{x} 1)$.

The signs were added by the main and the glossing hands. Roman numerals are used as section markers on ff. 53r, 111v, 118v and 129v. 


\section{St. Gallen, Stiftsbibliothek, MS 904}

Priscian, Institutiones grammaticae with glosses in Latin and Old Irish

c. 851, Ireland

http://www.e-codices.unifr.ch/de/list/one/csg/0904

$120 \mathrm{ff}$., Irish minuscule

BK 5870a; Lindsay, pp. 40-47; Kenney, p. 674

Most important signs: uersus (u, x160, sometimes with the tag gor for Georgica and bo for Bucolica), the o-shaped sign (x151), quaestio (Q/q, x67), cryphia ( $\bullet, \mathrm{x} 51)$, the Insular quotation sign (., x40),

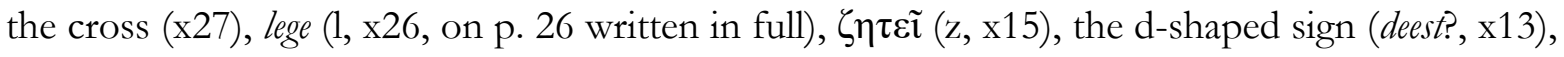

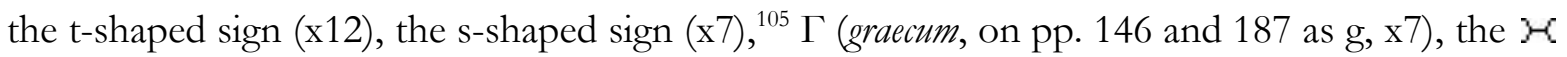
-shaped sign (x5), and two dots $(\bullet \cdot, x 5)$. Less frequently used or ambiguous signs include: the exshaped sign (exceptio, x11), the c-shaped sign (x5), trigon $(: ; \times 3)$, and the f-shaped sign (x2).

Just as Karlsruhe Priscian, St. Gallen Priscian features special locative signes de renvoi that connect material in different pages of the codex. Roman numerals were used as section markers in pp. 6 , 8, 29-30, 33, 45, 72, 78, 88, 140-42, and 214. With the exception of two omissions, which were indicated by a cryphia, omitted material is consistently marked by $\mathrm{d}$ and $\mathrm{h}$ signs.

The uersus signs appear in u-form as well as v-form and in some cases are rubricated. Signs were added by both the main and the glossing hands.

\section{Paris, Bibliothèque de l'Arsenal, MS 8407}

Psalms ('the Greek Psalter of Sedulius')

$9^{\text {th }}$ century, $3 / 4$, Continent

http://gallica.bnf.fr/ark:/12148/btv1b550008210

$66 \mathrm{ff} . .$, Greek majuscule and Irish minuscule

BK III 3932; Kenney, p. 557; Bischoff, 'Irische Schreiber', p. 51

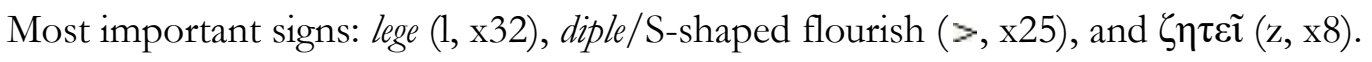

The signs were all made by the main hand. The famous subscription mentioning Sedulius Scottus

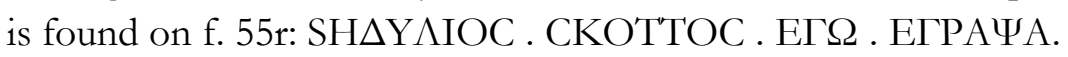

\footnotetext{
105 This sign does not seem to be either the S-shaped quotation symbol or the siglum for semper. The same sign is also found in Paris, Bibliothèque Nationale de France, MS Lat. 9382 ( $8^{\text {th }}$ century, in., Echternach). See for example ff. 17r and 17v; at: http://gallica.bnf.fr/ark:/12148/btv1b90767290/f25.item.
} 
Appendix II: sign forms occurring in the manuscript set

This appendix contains data about the absolute number of pages in each manuscript in which a particular technical sign appears. Its purpose is also to allow for a comparison of various sign forms.

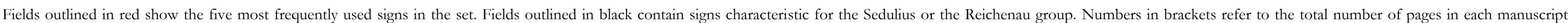

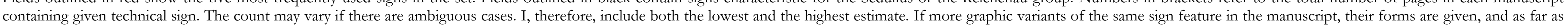
they seem to have distinct function, their counts are included in the same field and joined by a plus.

\begin{tabular}{|c|c|c|c|c|c|c|c|c|c|c|c|c|c|c|c|c|c|c|c|c|c|c|c|}
\hline manuscript & lege & $\zeta \eta \tau \varepsilon \tilde{\imath}$ & cross & $\begin{array}{l}\text { Insular } \\
\text { quotation } \\
\text { sign }\end{array}$ & trigon & graecum & require & c & chresimon & qauestio & deest & oculus & asteriscus & $\mathrm{e}$ & $\mathrm{s}$ & uersus & $T$ & $f$ & diple & M & cryphia & two dots & o \\
\hline $\begin{array}{l}\text { St. Gallen } \\
48\end{array}$ & $\frac{1}{(x 87-90)}$ & $\frac{5}{(x 12)}$ & $+_{(x 4)}$ & & & $\underset{(x 49)}{\Gamma^{2}}$ & $\begin{array}{c}y^{*} \\
(x 98-99)\end{array}$ & $\underset{(x 85)}{e}$ & $\dot{*}_{(\mathrm{x} 29)}$ & 4 & $\underset{(x 10)}{f}$ & $\underset{(\mathrm{x} 3)}{\odot}$ & - & (x3) & & & $\underset{(x 34)}{T}$ & & $>$ & $\underset{(\mathrm{x} 6)}{\ddot{M}}$ & & & \\
\hline $\begin{array}{l}\text { Basel A VII } \\
3\end{array}$ & $\begin{array}{c}\mathcal{L} \\
(\mathrm{x} 84)\end{array}$ & $\underset{(x 3)}{y}$ & & & & $\begin{array}{l}r \\
\Gamma_{A}(x 103 \\
+1)\end{array}$ & $\frac{\gamma^{\prime}}{(x 73)}$ & $\underset{(\times 34)}{C .}$ & $\underset{(x 11)}{\mathfrak{k}}$ & $\frac{9}{(x 1+1)}$ & to & & & & $\gamma_{(x 1)}$ & $\underset{(x 1)}{\gamma}$ & & $\underset{(x 2)}{f}$ & & & & & \\
\hline $\begin{array}{l}\text { Dresden A } \\
\text { 145b }\end{array}$ & $\frac{1}{(x 36-37)}$ & $\begin{array}{c}3 \\
(\mathrm{x} 62)\end{array}$ & $+(x 1)$ & & & $\frac{\pi}{(x 21-22)}$ & $\frac{\gamma^{2}}{(\mathrm{x} 6)}$ & $\begin{array}{c}c \\
(x 59)\end{array}$ & $f_{(\times 35)}$ & $\frac{1}{(x 48)}$ & $\frac{5}{(x 3)}$ & $\underset{(\mathrm{x} 2)}{\odot}$ & & $\frac{\mathbb{E}}{(\mathrm{x} 117)}$ & & & & & (x36) & & & & \\
\hline Bern 363 & $\underset{(x 96-98)}{\mathcal{L}}$ & 3 & tet & $\begin{array}{l}7 \\
(\mathrm{x} 282)\end{array}$ & (x2) & $\underset{(x 51)}{r}$ & $\frac{r}{(x 104)}$ & $\underset{(x 27)}{c}$ & $\frac{f .}{(x 172)}$ & $\begin{array}{c}1 \\
7 \\
(\mathrm{x} 293)\end{array}$ & $d \div$ & $\underset{(x 1)}{(c)}$ & $\therefore$ (x2) & & $\frac{-f \cdot}{(x 55)}$ & $\underset{(\times 33-35)}{v_{y}}$ & (x7) & $\underset{(x 125)}{\vec{p}}$ & & & & & \\
\hline $\begin{array}{l}\text { Karlsruhe } \\
\text { Aug. Perg. } \\
132\end{array}$ & $\sum_{(x 20)}$ & $\frac{2}{(x 1)}$ & $\begin{array}{c}4 \\
(x 42)\end{array}$ & $\cdots(\mathrm{x} 2)$ & $\therefore(x 3)$ & & & & & & & & & & & $\left.\tilde{v}^{*} \times 26-27\right)$ & & $\frac{F}{(x 1)}$ & & & & $\cdots_{(x G)}$ & $\begin{array}{r}0 \\
(\times 27) \\
\end{array}$ \\
\hline $\begin{array}{l}\text { Karlstuhe } \\
\text { Aug. Perg. } \\
167\end{array}$ & (x19) & $\underset{(\mathrm{x} 2)}{2}$ & +71 & $\begin{array}{l}\stackrel{3}{\div}(x 2 \\
+x 32+ \\
1)\end{array}$ & $\begin{array}{l}\because \cdot \\
(\mathrm{x} 1 ?)\end{array}$ & & & & & & & & & & & & & & & $M_{(x 5)}$ & & & (x8) \\
\hline $\begin{array}{l}\text { Karlsruhe } \\
\text { Aug. Perg. } \\
195\end{array}$ & $\underset{(x 35)}{\bigcup}$ & & $\pm_{(x 6)}$ & & ${ }_{2)}{ }_{(x 1-}$ & & & & & & $\frac{.5}{(x 7)}$ & & & & & & & & & & & & (x13) \\
\hline $\begin{array}{l}\text { St. Paul in } \\
\text { Lavanttal }\end{array}$ & & & & (x1) & $\mathrm{F}^{*}(\mathrm{x} 1)$ & & & & & & & & & & & $\bar{F}(x 1)$ & & & & & & & $0_{(x 3)}$ \\
\hline Pal. Lat. 68 & & & $\Psi_{(x 63)}$ & $\sum_{(x 90)}^{y}$ & & & & & & & & & & & & & & & & $\frac{\overline{f-c}}{(x 21)}$ & & & \\
\hline $\begin{array}{l}\text { Würzburg } \\
\text { M.p.th.f.12 }\end{array}$ & $\frac{2}{(x 6)}$ & & $\underset{(x 1)}{+}$ & (x3) & $\frac{{ }^{\prime}}{(\mathrm{x} 20)}$ & & & & & & & & & & & & & & & & & & \\
\hline $\begin{array}{l}\text { Milan C } 301 \\
\text { inf. }\end{array}$ & $\underset{(x 58)}{\ell}$ & 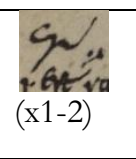 & $\frac{f}{(x 3)}$ & (x1) & $\begin{array}{l}\therefore \\
(\mathrm{x} 20-21)\end{array}$ & & & & & $\frac{9}{(x 3)}$ & & & & & & $\underset{(x 1)}{11}$ & & & & $\frac{2-c}{(x 3)}$ & & $\stackrel{\bullet}{(\times 36)}$ & \\
\hline $\begin{array}{l}\text { St. Gallen } \\
904\end{array}$ & $\begin{array}{r}2 \\
(\mathrm{x} 26)\end{array}$ & $\sum_{(x 14-15)}^{6}$ & $\underset{(x 26-27)}{F}$ & (x40) & $\therefore(x 3)$ & $\bar{f}(x 5+2)$ & & $\frac{C}{(\times 5)}$ & $f_{(x 1)}$ & $\begin{array}{l}9 \\
Q_{(x 9} \\
+58)\end{array}$ & $\frac{d}{(x 13)}$ & & & & $\gamma_{(x 7)}^{*}$ & $\underset{(\times 160)}{\mathcal{U}}$ & $\frac{f}{(x 12)}$ & $\underset{(x 2)}{F}$ & $\frac{\int_{(x 23)}}{(x)}$ & $\frac{x}{(x 5)}$ & $\underset{51)}{*}(x 50-$ & $\begin{array}{c}\ldots \\
(x 5)\end{array}$ & $\frac{0}{(x 151)}$ \\
\hline $\begin{array}{l}\text { Paris } \\
\text { Arsenal } \\
8407\end{array}$ & $1_{(x 32)}$ & (x8) & & & & & & & & & & & & & & & & & $\frac{5}{(\mathrm{x} 25)}$ & & & & \\
\hline
\end{tabular}


Images used in this appendix and the main text of this article were taken from the following folia or pages of the manuscripts (in the other from the left to the right):

St. Gallen, Stiftsbibliothek, MS 48: pp. 101, 245, 80, 207, 118, 76, 44, 103, 85, 220, 192, 300, 60, 64, 40, 64

Basel, Universitätsbibliothek, A VII 3: fols. 27r, 62v, 5v, 52r, 44v, 51r, 81r, 26r, 63v, 45r, 22r, 24v, 55r

Dres.

Bern, Burgerbibliothek, MS 363: fols. 5r, 19r, 34r, 60r, 156v, 146v, 31v, 16v, 14v, 16r, 28v, 30r, 29v, 145v, 108v, 13r, 190r, $7 \mathrm{v}$

Karlstuhe, Badische Landesbibliothek, Aug. Perg. 132: fols. 7r, 103v, 83v, 63v, 31r, 8r, 38v, 6r, 4

Karlsruhe, Badische Landesbibliothek, Aug. Perg. 167: fols. 20v, 36r, 24r, 25r, 25r, 26v, 20r, 26r

Karlsruhe, Badische Landesbibliothek, Aug. Perg. 195: fols. 2v, 13v, 10r, 10v, 6r

St. Paul in Lavanttal, Stiftsbibliothek, MS 86a/1: fols. 1v, 5v, 1v, 5v

Vatican, Biblioteca Apostolica Vaticana, Pal. Lat. 68: fols. 2v, 2r, 3v

Würzburg, Universitätsbibliothek, Mp.th.f. 12: fols. 16v, 10v, 2r, 20r

Milan, Biblioteca Ambrosiana, C 301 inf.: fols. 15v, 53r, 63v, 42r, 41r, 53r, 74r, 74v, 47v

St. Gallen, Stiftsbibliothek, MS 904: pp. 11, 9, 123, 12, 118, 12, 93, 205, 227, 6, 8, 99, 101, 101, 139, 12, 111, 6, 152, 141,6

Paris, Bibliothèque de l'Arsenal, MS 8407: fols. 2v, 24v, 5v 


\section{Appendix III: comparison of the frequency of sign use in the manuscript set}

This appendix contains data about the number of pages in the manuscripts containing particular technical signs in percentages (calculated to half percent). The higher the percentage, the larger part of the manuscript is annotated with a particular sign. It consists of two tables. Table a provides the comparison of the manuscripts from the set. Table b focuses on the activity of the hand of Bern 363 in the four manuscripts from the Sedulius group.

In order to make the data presented in this appendix easier to read, I colour-code them according to the following key:

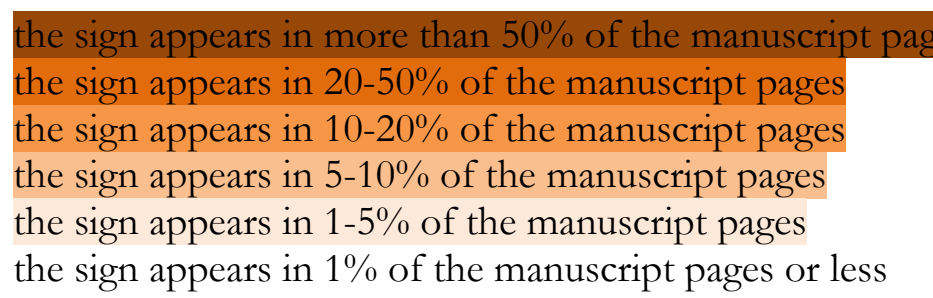

This classification of signs based on their frequency of occurrence is in itself revealing, as it makes clear that only some signs appear very frequently or on the contrary very rarely. For example, only a handful of signs appear frequently (more than $20 \%$ of pages) or very frequently (more than $50 \%$ of pages) in more than one manuscript. The Insular quotation sign is the only technical sign that occurs very frequently in more than one manuscript (specifically in two manuscripts, Bern 363 and Pal. Lat. 68). The prominent position of the lege sign in the Irish mode of annotation is confirmed by the fact that it features frequently in five manuscripts, that is in more manuscripts than any other sign. It is followed by the Insular quotation sign and the quaestio sign, which appear both in three manuscripts, and by the require correction sign, which appears frequently in two manuscripts from the Sedulius group. By contrast, the oculus and the asteriscus always appear in very small amounts.

Because the percentage of pages containing a certain sign do not depend only on the total number of such pages but also on the size of the manuscript, some of the differences in the frequency of occurrence should be ascribed to the varying size of the manuscripts in the set (from 8 folia to 198 folia). For example, a single occurrence of a sign in the 'Reichenauer Schulheft' would manifest as $6 \%$ of the manuscript pages because of the low total number of folia in this codex, while a single occurrence in St. Gallen 48, the largest manuscript in the set, would yield only $0.25 \%$. For this reason, this appendix should always be used together with Appendix II, which records the absolute number of pages containing particular signs, and its users should bear in mind its limits.

Percentages given in parentheses reflect the ambiguous cases, in which it is unclear whether graphic symbols in a certain manuscript represent the technical sign described in the article. The manuscript groups distinguished in this article are set apart in this article by thicker lines. 
a. Frequency of sign distribution in the manuscript set

\begin{tabular}{|c|c|c|c|c|c|c|c|c|c|c|c|c|c|c|c|c|c|c|c|c|c|c|c|}
\hline & 1 & $z$ & + & ., & $\therefore$ & $\Gamma$ & $\mathbf{r}$ & c & 米 & $q$ & d & $\Theta$ & $※$ & e & $\mathbf{s}$ & $\mathbf{v}$ & $\mathbf{T}$ & f & $>$ & M & $(*)$ & $\ldots$ & o \\
\hline $\begin{array}{l}\text { St. Gal. } \\
48\end{array}$ & $11 \%$ & $1.5 \%$ & $>1 \%$ & & & $6 \%$ & $\begin{array}{l}12.5 \\
\%\end{array}$ & $11 \%$ & $4 \%$ & $4 \%$ & $1 \%$ & $\begin{array}{l}>1 \\
\%\end{array}$ & $\begin{array}{l}>1 \\
\%\end{array}$ & $\begin{array}{l}>1 \\
\%\end{array}$ & & & $4 \%$ & & $4 \%$ & $1 \%$ & & & \\
\hline $\begin{array}{l}\text { Basel A } \\
\text { VII } 3\end{array}$ & $\begin{array}{l}42.5 \\
\% \\
\end{array}$ & $1.5 \%$ & & & & $\begin{array}{l}52.5 \\
\% \\
\end{array}$ & $37 \%$ & $17 \%$ & $\begin{array}{l}5.5 \\
\% \\
\end{array}$ & $\begin{array}{l}>1 \\
\%\end{array}$ & $\begin{array}{l}3.5 \\
\% \\
\end{array}$ & & & & $\begin{array}{l}>1 \\
\%\end{array}$ & $>1 \%$ & & $1 \%$ & & & & & \\
\hline $\begin{array}{l}\text { Dresden } \\
\text { A 145b }\end{array}$ & $19 \%$ & $31 \%$ & $>1 \%$ & & & $11 \%$ & $3 \%$ & $30 \%$ & $18 \%$ & $\begin{array}{l}24 \\
\%\end{array}$ & $\begin{array}{l}1.5 \\
\%\end{array}$ & $1 \%$ & & $59 \%$ & & & & & $18 \%$ & & & & \\
\hline Bern 363 & $25 \%$ & $8 \%$ & $2.5 \%$ & $\begin{array}{l}71.5 \\
\%\end{array}$ & $>1 \%$ & $13 \%$ & $26 \%$ & $7 \%$ & $44 \%$ & $\begin{array}{l}74 \\
\%\end{array}$ & $1 \%$ & $\begin{array}{l}>1 \\
\%\end{array}$ & $\begin{array}{l}>1 \\
\%\end{array}$ & & $\begin{array}{l}14 \\
\%\end{array}$ & $9 \%$ & $2 \%$ & $32 \%$ & & & & & \\
\hline $\begin{array}{l}\text { Karlsruh } \\
\text { e } 132\end{array}$ & $9 \%$ & $>1 \%$ & $\begin{array}{l}19.5 \\
\%\end{array}$ & $1 \%$ & $1 \%$ & & & & & & & & & & & $\begin{array}{l}12.5 \\
\%\end{array}$ & & $\begin{array}{l}>1 \\
\%\end{array}$ & & & & $3 \%$ & $\begin{array}{l}12.5 \\
\%\end{array}$ \\
\hline $\begin{array}{l}\text { Karlsruh } \\
\text { e } 167\end{array}$ & $19 \%$ & $2 \%$ & $3 \%$ & $33 \%$ & $(1 \%)$ & & & & & & & & & & & & & & & $5 \%$ & & & $8 \%$ \\
\hline $\begin{array}{l}\text { Karlsruh } \\
\text { e } 195\end{array}$ & $37 \%$ & & $6 \%$ & & $2 \%$ & & & & & & $\begin{array}{l}(7 \% \\
)^{(7 \%}\end{array}$ & & & & & & & & & & & & $14 \%$ \\
\hline $\begin{array}{l}\text { St. Paul im } \\
\text { Lavanttall }\end{array}$ & & & & $6 \%$ & $6 \%$ & & & & & & & & & & & $6 \%$ & & & & & & & $19 \%$ \\
\hline $\begin{array}{l}\text { Pal. Lat. } \\
68\end{array}$ & & & $\begin{array}{l}68.5 \\
\%\end{array}$ & $98 \%$ & & & & & & & & & & & & & & & & $\begin{array}{l}23 \\
\%\end{array}$ & & & \\
\hline $\begin{array}{l}\text { M.p.th.f. } \\
12\end{array}$ & $8 \%$ & & $1 \%$ & $4 \%$ & $28 \%$ & & & & & & & & & & & & & & & & & & \\
\hline $\begin{array}{l}\text { Milan C } \\
301 \text { inf. }\end{array}$ & $20 \%$ & $>1 \%$ & $1 \%$ & $>1 \%$ & $7 \%$ & & & & & $\begin{array}{l}(1 \% \\
)^{(1 \%}\end{array}$ & & & & & & $>1 \%$ & & & & $1 \%$ & & $12 \%$ & \\
\hline $\begin{array}{l}\text { St. Gal. } \\
904\end{array}$ & $11 \%$ & $6 \%$ & $11 \%$ & $17 \%$ & $1 \%$ & $3 \%$ & & $(2 \%)$ & $\begin{array}{l}>1 \\
\%\end{array}$ & $\begin{array}{l}28 \\
\%\end{array}$ & $\begin{array}{l}(5 \% \\
)^{(5 \%}\end{array}$ & & & & $3 \%$ & $67 \%$ & $5 \%$ & $\begin{array}{l}(>1 \\
\%)\end{array}$ & $\begin{array}{l}(9.5 \\
\%)\end{array}$ & $2 \%$ & $21 \%$ & $2 \%$ & $63 \%$ \\
\hline $\begin{array}{l}\text { Paris } \\
8407\end{array}$ & $24 \%$ & $6 \%$ & & & & & & & & & & & & & & & & & $\begin{array}{l}(19 \\
\%) \\
\end{array}$ & & & & \\
\hline
\end{tabular}

b. Technical signs made by the Bern hand in the four manuscripts from the Sedulius group

\begin{tabular}{|c|c|c|c|c|c|c|c|c|c|c|c|c|c|c|c|c|c|c|}
\hline & $q$ &., & \& & $f$ & $\mathbf{r}$ & 1 & $\mathrm{~s}$ & $\Gamma$ & $\mathbf{v}$ & $\mathbf{z}$ & c & + & $T$ & d & $\therefore$ & ※ & $\Theta$ & $\mathbf{M}$ \\
\hline Bern 363 & $\begin{array}{l}x 293 \text {, } \\
74 \%\end{array}$ & $\begin{array}{l}\times 282 \\
71.5 \%\end{array}$ & $\begin{array}{l}\mathrm{x} 172 \\
44 \%\end{array}$ & $\begin{array}{l}x 125 \\
32 \%\end{array}$ & $\begin{array}{l}\text { x104, } \\
26 \%\end{array}$ & $\begin{array}{l}\text { x98, } \\
25 \%\end{array}$ & $\begin{array}{l}x 56, \\
14 \%\end{array}$ & $\begin{array}{l}x 51, \\
13 \%\end{array}$ & $\begin{array}{l}\times 35 \\
9 \%\end{array}$ & $\begin{array}{l}x 32, \\
8 \%\end{array}$ & $\begin{array}{l}\mathrm{x} 19, \\
5 \%\end{array}$ & $\begin{array}{l}\mathrm{x} 10, \\
2.5 \%\end{array}$ & $\begin{array}{l}x 7, \\
2 \%\end{array}$ & $\begin{array}{l}\mathrm{x} 5, \\
1 \%\end{array}$ & $\begin{array}{l}\mathrm{x} 2 \\
>1 \%\end{array}$ & $\begin{array}{l}\mathrm{x} 2 \\
>1 \%\end{array}$ & $\begin{array}{l}\mathrm{x} 1, \\
>1 \%\end{array}$ & - \\
\hline Dresden A 145b & $\begin{array}{l}\mathrm{x} 20 \\
80 \%\end{array}$ & $\begin{array}{l}\mathrm{x} 22 \\
88 \%\end{array}$ & $\begin{array}{l}x 5 \\
20 \%\end{array}$ & - & - & $\begin{array}{l}\mathrm{x} 17, \\
68 \%\end{array}$ & $\begin{array}{l}\mathrm{x} 8 \\
32 \%\end{array}$ & $\mathrm{x} 1,4 \%$ & - & $\mathrm{x} 1,4 \%$ & $\begin{array}{l}x 7 \\
28 \%\end{array}$ & - & - & - & - & - & - & $\begin{array}{l}\mathrm{x} 16, \\
64 \%\end{array}$ \\
\hline Basel A VII 3 & $\mathrm{x} 1$ & $\mathrm{x} 1$ & - & $\mathrm{x} 1$ & - & $\mathrm{x} 1$ & x3 & $\mathrm{x} 1$ & - & $\mathrm{x} 1$ & $\mathrm{x} 4$ & - & - & - & - & - & - & - \\
\hline St. Gallen 48 & - & - & $\mathrm{x} 1$ & - & - & - & - & - & - & $\mathrm{x} 1$ & - & - & - & - & - & - & - & - \\
\hline
\end{tabular}

